School of Finance

University of St.Gallen

THE SOURCES OF RISK SPILLOVERS AMONG U.S. REITS: FinANCIAL CHARACTERISTICS AND REgIONAL PROXIMITY

ZENO ADAMS

ROLAND FÜSS

FELIX SCHINDLER

WORKING PAPERS ON FINANCE No. 173

SWISS INSTITUTE OF BANKING AND FINANCE (S/BF - HSG)

MAY 2011 


\title{
The Sources of Risk Spillovers among U.S. REITs: Financial Characteristics and Regional Proximity
}

\author{
Zeno Adams ${ }^{\dagger}$, Roland Füss ${ }^{\ddagger}$, and Felix Schindler ${ }^{\S}$
}

\section{Working Paper}

First version: May 2011

This version: June 2013

${ }^{\dagger}$ Swiss Institute of Banking and Finance (s/bf), University of St.Gallen, Rosenbergstrasse 52, 9000 St. Gallen, Switzerland, Phone: +41 (0)71 224-7057, Fax: +41 (0)71 224-7088, Email: zeno.adams@unisg.ch.

${ }^{\ddagger}$ Corresponding author: Swiss Institute of Banking and Finance (s/bf), University of St.Gallen, Rosenbergstrasse 52, 9000 St. Gallen, Switzerland and Research Associate at the Centre for European Economic Research (ZEW), Mannheim, Germany; Phone: +41 (0)71 224-7055, Fax: +41 (0)71 224-7088; Email: roland.fuess@unisg.ch.

$\S$ Senior Researcher at the Centre for European Economic Research (ZEW), L 7, 1, D-68161 Mannheim, Germany and Assistant Professor at the Center for Real Estate Studies (CRES) at the Steinbeis University Berlin (SHB), Berlin, Germany, Phone: +49 (0)621 1235-378, Fax: +49 (0)621 1235-223, Email: schindler@zew.de.

Acknowledgement: We are indebted to Brent Ambrose, David Geltner, Joseph T.L. Ooi, Seow Eng Ong, Tien Foo Sing, Vincent Yao, two anonymous referees, and the participants of the Research Seminar at the Real Estate Department of the National University of Singapore (NUS), the $40^{\text {th }}$ Annual Mid-Year Meeting Washington DC, the European Real Estate Society Annual Conference 2012, the Asian Real Estate Society (AsRES) and the American Real Estate and Urban Economics Association (AREUEA) International Conference 2012, Singapore, the NUS-MIT-Maastricht 2012 Real Estate Finance and Investment Symposium, Singapore, and the NAREIT-AREUEA Research Conference 2013, Chicago. Adams and Füss acknowledge financial support from the University of St.Gallen, Basic Research Fund - Project Grant 2130880. 


\title{
The Sources of Risk Spillovers among U.S. REITs: Financial Characteristics and Regional Proximity
}

\begin{abstract}
In this paper, we estimate the risk spillovers among 74 U.S. REITs using the statedependent sensitivity value-at-risk (SDSVaR) approach. This methodology allows for the quantification of the spillover size as a function of a company's financial condition (tranquil, normal, and volatile REIT prices). We show that the size of risk spillovers is more than twice as large when REITs are in financial distress and find evidence for the impact of geographical proximity: REITs that have their properties located in close distance to the properties of other REITs show risk spillovers that are on average 33\% higher than REITs that have similar properties but at a larger distance. We estimate the risk gradient to decrease nonlinearly and to have zero slope for property distances of more than 250 miles. Our empirical findings provide first empirical evidence on the transmission of risk spillovers from underlying real positions to the securitized level of a company. Specifically, our results provide new insights concerning the relevance of geographical diversification for REITs and have important implications for the investment and risk management decisions of real estate investors, mortgage lenders, home suppliers, and policy makers.
\end{abstract}

Keywords: $\quad$ REITs, fundamental value, geographic diversification, information diffusion, risk spillovers, state-dependent sensitivity VaR (SDSVaR).

JEL-Classification: $G 01, G 10, R 12$ 


\section{Introduction}

Risk managers in the real estate industry during the 2007-09 financial crisis were confronted with unanticipated risk spillovers among real and financial assets of unprecedented scale. In this paper, we propose a state-dependent sensitivity value-at-risk (SDSVaR) for quantifying risk spillovers among 74 U.S. Real Estate Investment Trusts (REITs). We explicitly account for the financial condition of a company during shock exposure. We show that size and persistence of these spillovers differ significantly for tranquil, normal, and volatile periods of real estate stock prices. Thereby, we are able to identify the direction of spillover effects from one REIT to another. In contrast to other publicly traded companies, REITs share a distinct spatial component in their fundamental value that impacts risk spillovers. We explicitly account for these spatial characteristics of REITs' property holdings. Due to their particular legal constraints and their straightforward business operations REITs provide, compared to industry companies, an interesting laboratory to test how spatial proximity in the underlying properties increase risk spillovers on the stock level. ${ }^{1}$ In addition to geographic distance, we identify a number of financial characteristics that increase the exposure of REITs to risk spillovers from other REITs. In particular, we show that high leverage, size, and market beta substantially increase the vulnerability to risk in other REITs, increasing the probability of contagion during a financial crisis.

${ }^{1}$ REITs generate almost their entire income from selling, managing, and owning real estate whereas the company value of many other firms is more related to human capital or to products that are movable and hence do not exhibit a certain geographical characteristic. In contrast, the value of a REIT is closely linked to the value of its properties and is much easier to measure than the fundamental value of industrial firms. The underlying properties of REITs can be valued almost precisely by appraisers based on the information such as property's income, age, quality, size, location, as well as transactions in comparable properties in neighboring regions and the recent past (Patel, Pereira, and Zavodov, 2009). 
A number of recent studies have investigated time-varying correlations among securitized real estate investment companies, in particular REITs. ${ }^{2}$ These studies generally verify two stylized facts that have been already documented in the stock market literature: $(i)$ correlations among equity markets vary considerably through time and (ii) stock market correlations increase in periods of high volatility (e.g., Bailey and Stulz, 1990; Bekaert, Harvey, and Ng, 2005; Solnik, Boucrelle, and Le Fur, 1996; Goetzmann, Li, and Rouwenhorst, 2005). These findings have important implications for the diversification potential of REITs in a traditional stocks and bonds portfolio. In the present study we contribute to this literature in three important ways.

First, our focus is on risk spillovers rather than return correlations. This shift in perspective from diversification to risk management comes with a subtle but important change in the way our results can be interpreted. In contrast to time-varying correlation models that simply measure the non-directional co-movement between assets, our spillover estimates not only quantify the size but also the direction of the spillover. We thereby control for other relevant factors such as general market movements in order to give our results a causal interpretation.

Second, we account for an important lesson of the 2007-09 financial crisis: the size of risk spillovers depends significantly on the market state or financial condition of a firm (see, e.g., Adrian and Brunnermeier, 2011; Brownlees and Engle, 2011; Acharya et al., 2010). ${ }^{3}$ For measuring risk spillovers this has the important consequence that the traditional ordinary least squares methodology that measures the average response in the dependent variable for a one

${ }^{2}$ Securitized real estate investment companies mainly consist of REITs, but also include listed property stocks and real estate operating companies (REOCs). In this study we will, however, focus on REITs only.

${ }^{3}$ A few studies have investigated this asymmetry in spillover behavior even before the 2007-09 financial crisis. For instance, Bae, Karolyi, and Stulz (2003) emphasized as early as 2003 that "large negative returns are contagious in a way that small negative returns are not.” 
unit change in the independent variable is no longer valid because risk spillovers do not occur on average but only during times of financial distress. We address this issue in a statedependent sensitivity value-at-risk (SDSVaR) model that allows us to discriminate between various conditions of financial health of a firm. We thereby model the risk spillovers for different quantiles of a REIT's risk distribution directly rather than splitting the data in two or more samples. This has the advantage of retaining the full sample size while addressing risk spillovers in the tails of the distribution. We find risk spillovers to increase substantially when the stock prices of the REIT that is exposed to a shock are in a volatile state.

Third, we incorporate a crucial feature that distinguishes REITs from other publicly listed companies: The spatial aspect of the properties owned by the REIT. We show that the extent to which a REIT is exposed to risk spillovers is mainly determined by geographic distance. REITs that have their properties located in close distance to the properties of other REITs show risk spillovers that are on average 33\% higher than REITs that have similar properties but at a larger distance. As we increase geographic distance, risk spillovers fall quickly and remain at a lower level for all property distances of more than 250 miles. Our empirical findings concerning the impact of distance suggest that the effectiveness of geographic diversification may be lower than previously thought. Individually, REITs may appear geographically diversified, but in aggregate, they may be highly exposed to risk spillovers from other REITs that have their properties located in the same regions. More importantly, this type of interdependency among REIT returns is not detected by the usual sample correlations which is a measure of the average relationship between returns. In contrast, risk spillovers are a phenomenon that only occurs during a financial crisis. Thus, a REIT portfolio that is guided by the usual correlation matrix will fail to reveal the full extent of risk in real estate investment trusts. 
The direction of the paper is as follows. In the next section we present a brief overview of the literature that has investigated spillovers in real estate markets. In section 3 we discuss theoretical motivations for the transmission mechanism of shocks and the role of geographical distance. In section 4 we present a model of risk spillovers among single REITs, thereby controlling for a number of variables that affect all REITs in a similar way. This allows for a disentanglement of spillovers from more general co-movements and gives our spillover estimates a causal interpretation. Section 5 investigates a number of financial variables that affect the size of risk spillovers and presents counterfactual results using impulse response functions. The final section contains the conclusion.

\section{Literature Review}

The literature on spillover effects in real estate markets can be broadely divided into two main categories. One group of papers investigates spillovers using high frequency timeseries data and often has a focus on the methodological aspect of spillovers. Another group of work explores spillovers on a more fundamental economic level with a focus on the spatial propagation of shocks. Prominent examples of the first category are for instance Chen and Liow (2006) who investigate the transmission of volatility among the major REIT markets and find that volatility spillovers are more pronounced within Asian economies. Cotter and Stevenson (2006) investigate risk spillovers among daily returns of equity, mortgage, and hybrid REITs but find little evidence for the existence of spillovers. Elyasiani, Mansur, and Wetmore (2008) find shocks to REIT volatility to spill over to the market of other financial institutions such as savings and loan associations as well as life insurance institutions. Hoesli and Reka (2011) focus on the methodological aspect of spillovers and present a time-varying copula framework that is explicitly designed to measure the dynamics between the tails of REIT returns. In this paper, we model spillover effects in a way that is similar to the above 
mentioned literature, but with the additional aim of being able to interpret risk spillovers in a causal way. When modeling risk spillovers, our approach also distinguishes between different levels of volatility. In the general finance literature this aspect has been shown to be of major importance (Adrian and Brunnermeier, 2011; Brownlees and Engle, 2011; Adams, Füss, and Gropp, 2013). ${ }^{4}$

The second group of papers concentrates on the spatial propagation of economic shocks to neighboring regions. The spatial distance that is investigated can range from a few hundred meters for direct neighborhood effects to longer distance neighboring cities or MSAs. For instance, Harding, Rosenblatt, and Yao (2009) show that the negative externality associated with deferred maintenance and neglect of a foreclosed property can lower house prices by $1 \%$ per nearby foreclosed property. In these types of studies the transmission mechanism of a foreclosed property is largely visual. ${ }^{5}$ The long-range propagation of spillovers has been investigated by a number of studies with Meen (1999) being one of the earlier and perhaps most relevant papers. Meen (1999) concludes that the national housing market can be described by a series of interlinked local markets. ${ }^{6}$ In his paper, he explains the observed linkages by investor behavior, consumer behavior, and interlinked economic bases. Higher house prices in one region create incentives for investors to buy homes in nearby regions that

\footnotetext{
${ }^{4}$ In the real estate literature, more recent studies have also acknowledge the large impact that varying economic conditions can have on risk spillovers. Miao, Ramchander, and Simpson (2011) model the "active phase” of the market using the time period 1999-2006 and a calm market phase from 1989-1998 and report substantially stronger linkages in the active phase. Zhu, Füss, and Rottke (2011) support these findings with a similar observation of increased co-movements among regional house prices during the 2007-2009 financial crisis.

${ }^{5}$ See also Ioannides (2003), Immergluck and Smith (2006), and Lin, Rosenblatt, and Yao (2009) for important findings concerning spillovers in the immediate neighbourhood.

${ }^{6}$ Although most studies use data for single family houses (see, e.g., Cromwell,1992 and Pollakowski and Ray,1997 for the U.S. market and MacDonald and Taylor, 1993 and Alexander and Barrow, 1994 for the U.K. market) the spatial aspect extends directly to all property types.
} 
did not experience this house price increase. ${ }^{7}$ This would result in spillovers and diffusion of the initial house price increase. Furthermore, house prices in two regions are linked if lower prices in one region attract more migration flows than the other region. In a study for the U.K. housing market, however, Meen (1999) reports that migration flows are weak and points to empirical work showing that migration flows are not much influenced by regional house price differences (Gordon, 1990). Finally, even if housing markets are not directly linked there may be underlying local characteristics such as employment and income levels that may themselves be linked interregionally leading to dependencies in housing markets across regions. This effect is the focus in a U.S. study of Coulson, Liu, and Villupuram (2010) who show that local employment and house prices are significantly driven by certain locally concentrated industries. For instance, the automobile industry is relevant for house price changes in Detroit while high technology plays a crucial role for the economic bases of Seattle and San Jose. Other studies that focus on the link between local economic bases and housing prices are Abraham and Hendershott (1996), Malpezzi (1999), and, more recently, Zhu, Füss, and Rottke (2011).

Since the basic model of spatial equilibrium in urban economics predicts that owneroccupied housing and income-producing properties are driven by common fundamental demand and supply sources (see, e.g., Rosen, 1979; Roback, 1982; Glaeser, Gyourko, and Saiz, 2008), we can assume that similar linkages exist for commercial real estate (see also Gyourko, 2009). In our paper, we contribute to the existing literature on the spatial propagation of shocks by estimating an explicit functional form for the relationship between risk spillovers and geographic distance. The slope of this risk gradient is an estimate of the impact of local economic shocks on REITs in neighboring regions. The standard approach in

${ }^{7}$ Rising house prices also create concurrent wealth effects for existing homeowners, again generating incentives to invest in the housing market of the lower priced region (Miao, Ramchander, and Simpson, 2011). 
the literature would be to use monthly or quarterly data on house price changes in different regions. However, the low frequency of that data would prevent us from modeling the distribution tails and hence the risk spllovers during crisis periods. In contrast, the approach in our paper is to combine the advantages that come with the abundance of high frequency daily data with the spatial information concerning the properties owned by REITs in order to estimate the link between geographic distance and risk spillovers.

\section{The Mechanism of Risk Transmission from Direct to Securitized Real Estate}

In this section we investigate possible risk transmission mechanisms as an attempt to explain empirically observed differences in some REITs' responses to exogeneous shocks. We use the insights from this section to form expectations concerning the empirical results of this paper. Due to their straightforward nature of operations, REITs provide an excellent laboratory to analyze how specific fundamental information is incorporated into stock prices, and how shocks in the fundamental value transmit to the securitized level. We argue that the specific response of a REITs VaR depends on (1) the type of the exogeneous shock (pure stock market shock versus local economic shock) and (2) the degree to which a REIT is vulnerable or exposed to risk in other REITs.

We distinguish between two different types of shocks that lead to risk spillovers among the stock prices of REITs. One type of shock is based on the underlying economic fundamentals affecting REITs and their property holdings, the other type reflects pure stock market linkages which can exist independently of changes in the underlying economic variables. When measuring spillovers, the challenge during the estimation step is to control for simple co-movements. Co-movements are situations in which REITs respond to a common economic or financial shock. For instance, changes in the interest rate-or expectations thereof-or changes in economic activity that take place on the national level 
induce responses from all REITs. The main disadvantage of co-movements is that we cannot measure the contagion character of risk among REITs as it is unclear how the risk in one REIT is responding to the risk in another REIT. In this study, we therefore concentrate on risk spillovers, which are situations in which higher risk in one REIT is actually causing higher risk in another REIT. In other words, we have a source of risk and a receiver of risk which allows for the estimation of risk transmission and hence for the systemic character of risk. Distinguishing co-movements from spillovers is challenging in practice and we have devoted substantial effort to the process of selecting the right control variables to achieve this goal

Risk spillovers from changes in underlying economic factors are therefore likely to come from local economic shocks that propagate to neighboring regions rather than national economic shocks. For instance, an adverse shock in a concentrated industry like the automobile industry in Detroit is particularly relevant for REITs that own properties in that region. When the information on the regional economic shock diffuses into the market, investors will anticipate the future layoffs in the service sector as well as losses in rental income from residential properties. Selling pressure on stocks of office and residential REITs will then be triggered by spillover effects from industrial and retail REITs. This is because income-producing residential stock constitutes denser multifamily houses which are more likely to be located in the central city of a metropolitan area. To revisit the example from above, the closing of a car factory and the subsequent drop in purchasing power from layoffs in the supporting industry will have a direct effect on industrial and retail REITs. Over time, some workers will relocate to other regions for a new job thereby increasing the supply of vacant residential properties. This will lead to sectoral spillovers from one type of REIT to another. 
A second example for spillovers due to a local economic shock would be a regional spillover. A drop in residential property values in the immediate area of the local economic shock dissipates to other nearby adjacent regions. In both cases however, the sectoral and the regional spillover constitute a propagation of risk from one REIT to another, similar to lending relationships between mutual portfolio holdings among financial institutions (Brunnermeier and Pedersen, 2009).

We should expect most risk spillovers to have their source in underlying economic changes. However, it could also happen that shocks are propagated purely via financial market linkages. This type of spillover may be uncoupled from economic fundamentals and corresponds to the observation that short-run price movements of REITs are closely aligned with the general stock market (Glascock, Lu, and So, 2000). Our empirical approach therefore also demands for the inclusion of variables that can capture the linkages of REITs with the stock market. A discussion of our variables follows in the data section below.

Other important variables that can increase the exposure of REITs to risk spillovers are the balance sheet characteristics of the REITs themselves. For instance, the profitability of a highly leveraged REIT is more sensitive to bad news such as lower than expected net operating income. Such a REIT may be therefore more susceptible to shocks from another REIT. By the same argument, the financial health of a REIT is likely to be an important factor. Consider a REIT that is under pressure from rapidly declining equity as a consequence of a series of failing property investments. This state of financial distress is reflected in highly volatile stock prices. In other words, the REIT has depleted its capital buffer to absorb any shocks and is highly vulnerable to any bad news. Under these circumstances, a shock in one REIT is likely to have a much higher impact on the distressed REIT than the same shock under normal or tranquil circumstances. 
We summarize our arguments on how local proximity of property holdings and REIT characteristics affect risk spillovers among REITs in Figure 1. Panel A shows the different types of shocks on the fundamental and financial level. National and local economic effects influence REIT prices either directly or indirectly through future expected fundamental values. The volatility in the REITs' stock returns is furthermore driven by the balance sheet characteristics of the REITs as well as the state of their financial health. Panel B of Figure 1 shows how the individual risk channels add up to the observed spillovers among REITs and highlights the special role of distance as an indicator whether two REITs are exposed to the same or similar local economic shocks. Furthermore, we expect risk spillovers to shift upwards if the shock receiving REIT has above average leverage. Risk increasing characteristics accumulate. For instance, the risk spillovers are further increased if in addition to higher leverage, the shock receiving REIT is in a state of financial distress. From Figure 1 we draw two conclusions for this section: We expect risk spillovers to be higher for REITs that own properties in similar regions. However, we also expect to find positive spillovers between REITs without significant spatial linkages but with certain balance sheet and financial health characteristics which favour higher risk spillovers. The degree to which this is the case is an empirical question and will be answered in the following sections.

$<<<$ Figure 1 about here $>>>$

\section{Data}

In the previous section we have discussed the transmission channels of risk. We also highlighted the importance of separating spillovers from mere co-movements. While the first point indicates a number of variables that may be important in explaining differences in risk spillovers, the second point hints at important control variables. The empirical part in this paper is divided in a section that focuses in "risk spillover measurement", and another that focuses on "risk spillover explanation”. Each part serves a different purpose and is based on 
slightly different data and methodology. For instance, the measurement of risk spillovers is based on time-series of daily traded stock prices of REITs. The explanation of risk spillovers, in contrast, is based on a cross-section of REIT characteristics. We will therefore present the data in different subsections.

\subsection{Data for the Time-Series Model}

We retrieved the information regarding the property holdings of REITs from SNL financial at the beginning of 2011. At that time there was information on 158 REITs available $^{8}$. We subsequently had to remove a number of REITs for one of the following reasons:

- No information regarding property holdings was available.

- The REIT had an insufficient return history.

- The location of the properties was incorrect.

- The time-series of REIT returns showed infrequent trading.

- A few REITs had a significant number of properties located outside the U.S. (mainly in Mexico, Canada, and the U.K.).

We used the daily stock returns over the period 06/01/2007 to 03/16/2011 (956 observations) on the remaining 74 REITs. We also correlated the average return over all 74 REITs with the return of the general U.S. REIT index from Standard and Poor's. A correlation coefficient of 0.9843 indicates that the missing REITs in our sample can be considered random draws from the population and do not represent a particular group of REITs that would differ in any systematic way from our existing 74 companies. In the timeseries approach we also use a number of control variables that serve to distinguish spillovers from co-movements. These are daily data on the general U.S. REIT index from S\&P, the

\footnotetext{
${ }^{8}$ We did not include Real Estate Operating Companies (REOCs) which are also in the SNL data base.
} 
Russell 2000 small cap stock index, and an indicator of economic activity. The economic activity variable is measured in monthly frequency for all U.S. states.

\subsection{Data for the Cross-Sectional Model}

In the cross-sectional model, the dependent variable is constructed from output of the time-series model. In particular, the dependent variable is the risk spillovers estimates to be discussed in the next section. ${ }^{9}$ The property holdings for individual REITs are obtained from the SNL databank at the reference date 2011Q1. Figure 2 shows descriptive statistics of the typical number of properties owned by a REIT and the property size (in sqm) for different property sectors. For instance, Panel A shows that the median number of properties for retail REITs is 128 and that $75 \%$ of industrial REITs have properties that are 14,576 sqm in size or more. Panel B of Figure 2 also shows a map of the locations of properties. All types of properties form clusters that are predominant along the costal regions.

$$
<<<\text { Figure } 2 \text { about here }>>>
$$

REITs are subject to certain property-selling restrictions that are required in order to maintain their tax-exempt status. For instance, REITs must hold acquired properties for a minimum period of four years. Furthermore, they are not allowed to sell more than $10 \%$ of their net asset base within a given tax year (see, e.g., Mühlhofer, 2011). Empirical studies on the actual holding periods of commercial property in the U.S. find an average holding period of 11 years (Fisher and Young, 2000). In a study for the U.K. market, Collett, Lizieri, and Ward (2003) find that this average is higher during market downturns when returns are lowest and disposition of a property would result in a loss for the investor. This effect is

${ }^{9}$ The use of estimated as opposed to actually observed spillovers in the cross-sectional setting does not cause an estimation problem because the estimated price series assumes the role of the dependent variable in our cross-section model rather than that of an independent variable. That means we are adding a measurement-inerror problem to the left side of the second stage regression rather than to the right side. As is well-known, dependent variables measured with error do not cause a fundamental estimation issue because the measurement error is captured in the usual regression error term. 
further amplified by restricted access to financing, lower liquidity, and hence higher transaction costs increasing holding periods even further. This provides support for a necessary assumption in the empirical section of our paper: we assume property holdings to remain constant during our period of investigation (2007 - 2010) which includes the 2008-09 financial crisis period. The following five regressors are obtained from the balance sheets of the REITs (from the SNL datrabank) and are measured as average annual values between 2007 and 2010, the time period over which the risk spillovers were estimated (time period 06/01/2007 to $03 / 16 / 2011$ ). The sixth regressor is estimated from monthly market data over the same period. The selected REITs in our sample are mainly domestically invested, only a few properties are located in Canada or Mexico. However, given the large number of included properties, their impact is negligible.

1. Property type: In a recent study, Chiang (2010) shows that price co-movements among REITs within the same property type have increased over time. If the prices of some property types are more sensitive to changes in economic conditions than others risk spillovers among specialized REITs are likely to differ as well. ${ }^{10}$ Chiang argues that the information openness due to high institutional participation, low insider ownership, and large market capitalization supports the price discovery process of property-type information and the pricing on firm level. Capozza and Seguin (1999) show that REITs with a strong sector focus are less complex in monitoring and more transparent than REITs holding diversified portfolios.

2. Size: Large REITs tend to be represented with properties in many regions across the country and may be therefore more exposed to local economic shocks at different

${ }^{10}$ If at least $90 \%$ of a REIT's properties are of the same property type we classify this REIT as the corresponding type. Most REITs are classified as being either retail (25), office (24), or residential (19) REITs. Only six REITs were classified as industrial. A complete list of the REITs used in the empirical part is given in Table A1 in the Appendix. 
locations. Moreover, in line with the arguments of Chiang (2010), prices of largecapitalized REITs may contain a higher degree of systematic information. Finally, Sun, Titman, and Twite (2013) have argued recently that large REITs were to a significant extent owned by institutional investors that were forced to sell assets during the crisis. This idea of overreaction is supported by the fact that large REITs also experienced the strongest rebound after the crisis. Size is approximated by total enterprise value, i.e. company's debt plus equity.

3. Leverage: Although REITs rely heavily on leverage to finance commercial properties we expect the importance of leverage for risk spillovers among REITs to be somewhat lower than for financial institutions. ${ }^{11}$ This is because financial institutions use leverage to hold each others assets in their portfolio so that in the presence of a shock, spillovers occur when financial institutions sell other institutions stocks. Still, REITs with higher leverage are associated with higher risk and are therefore more likely to react stronger to risk spillovers (see Cici, Corgel, and Gibson, 2011). Leverage is computed as total assets divided by total book equity.

4. Maturity mismatch: Companies that have the majority of their debt denominated as short-term debt are generally in greater need of cash and hence more sensitive to losses and market distress. This should be particularly prevalent in market periods where investors prefer liquidity and refinancing conditions tighten. We expect companies with a large maturity mismatch to be more sensitive to risk spillovers. Maturity mismatch is defined as [short-term debt plus debt due this financial year minus cash] divided by total liabilities.

${ }^{11}$ The median leverage of the REITs in our sample is approximately three, i.e. two-thirds of the capital is debt. Prior to the early 2000's when REITs started to increase their leverage, REITs typically had no more than a one-to-one debt-to-equity ratio (see also Gyourko, 2009). 
5. Market-to-book: Past empirical evidence has shown that some investors tend to overinvest in stocks that have done very well in the past contributing to an overpricing of such stocks (Lakonishock et al., 1994, Griffin and Lemmon, 2002). Similarly, it has been observed that investors tend to overreact to stocks that have performed very poorly pushing their prices below their fundamental value. Since investors eventually realize that the past performance of many REIT stocks does not prevail in the future we expect stocks with high market-to-book values to be more sensitive to risk spillovers.

6. Market beta: Taking the S\&P 500 composite index as the market return we use the beta of a REIT as an indication of its general stock market linkage. The stock market linkage is likely to be an important source of risk spillovers for REITs that have no direct spatial dependence. We expect firms that have high betas and thus a stronger dependence on stock market movements to be more exposed to risk spillovers.

An overview of these financial variables is given in Figure 3. Maturity mismatch is given in percent of total liabilities and size is measured in millions of U.S. dollars. Compared to financial institutions, leverage is relatively low among REITs. In addition, only a small fraction of total liabilities is in the form of short-term debt which is reasonable given their long investment horizon. One potentially important variable not included in our model is REIT liquidity. Liquidity becomes relevant when a price drop in REIT $j$ induces investors to sell the stocks of REIT $i$. If REIT $i$ 's stocks are illliquid the price impact from trading REIT $i$ and hence the spillover from $j$ to $i$ will be larger. However, liquidity is typically strongly time-varying. A measure of average liquidity in a cross-sectional setting spanning a four year period would be uninformative. What is relevant for explaining the variation in spillovers is 
not the average liquidity but the amount of liquidity at the moment when the spillover occurs. $^{12}$

In estimating the cross-sectional model we treat the financial variables as categorical instead of continuous variables. Recall that the cross-section consists of 5,402 observations obtained from regressing all combinations between two of the 74 REITs. Accordingly, among the 5,402 observations in the sample only 74 values of each variable are unique and each value is repeated 73 times. In addition, the values are distributed very unevenly over the range of the variables with clusters for low, middle, and high values. This clustering of values is demonstrated in the lower panel of Figure 3 for the variable leverage. ${ }^{13}$ We therefore split each variable in three categories. The first decile represents low values of that category, and the last decile representing the upper end of the variables. Grouping the variables in this way allows for a clear distinction between the values. Note, for instance, that the first and third quartile as shown in Panel A for leverage are quite close together. Our results still hold for more moderate classifications but are less clear and become mixed for cut-off points that are closer to the median such as 0.3 and 0.7 , respectively.

$$
<<<\text { Figure } 3 \text { about here }>>>
$$

\footnotetext{
12 Marshall, Nguyen, and Visaltanachoti (2012) furthermore show that more generally, low frequency measures are not suitable for capturing the underlying liquidity of an asset. We also estimated a version of Equation (4) that includes illiquidity in an interaction term with the VaR of REIT $j$. In contrast to the crosssectional setting that required to take the time mean over a REIT's liquidity, Equation (4) estimates the spillovers in a time-series that allows for the inclusion of the daily variation in liquidity. Our results (not shown) were however inconclusive. Although the spillover coefficients are very close to the ones reported in Table 1, our Amihud illiquidity measure (daily absolute returns divided by volume) was only significant in 50\%, 29\%, and $14 \%$ of all times for volatile, normal, and tranquil periods, respectively. A further disadvantage of this approach is that the marginal spillover effects become hard to interpret as the interpretation relies on a given level of liquidity. Because of the high variability in liquidity, the usual approach of inserting the average liquidity could not be applied.

13 The distributions for the other variables look very similar. The only variable that does not indicate strong clustering is market beta. In order to be consistent we also transformed this variable into categorical form but the empirical results are similar when beta enters the model as a continuous variable.
} 
Finally, we construct a measure of geographical distance between any combination of two REITs. This task is complicated by the fact that a meaningful measure has to be based on the geographic location of the properties that are owned by the REITs. We obtain information on the latitude and longitude of all 16,418 properties which are distributed over the 74 REITs. Distance $D$ is computed using the Haversine formula which gives the shortest distance over the earth's surface ${ }^{14}$ :

$$
D=R \cdot C
$$

where $R$ is the earth's radius (3,959 miles), $c=2 \cdot \operatorname{atan}_{2}(\sqrt{a}, \sqrt{1-a})$, $a=\sin ^{2}(0.5 \cdot \Delta l a t)+\cos \left(l_{1} t_{1}\right) \cdot \cos \left(l a t_{2}\right) \cdot \sin ^{2}(0.5 \cdot \Delta l o n g)$, and lat and long are the latitude and longitude of a property measured in radians.

To determine the distance between two REITs, say REIT $i$ and REIT $j$, we successively compute the distance of each property in REIT $i$ to all other properties owned by REIT $j$ in order to identify the property of REIT $j$ with the shortest distance to the properties of REIT $i$. This approach follows the intuition that we are particularly interested in the presence of nearby properties which are affected by the same local economic conditions. ${ }^{15}$ Having detected the nearest properties of REIT $j$ for all properties of REIT $i$, we take the average over all distances of those properties to find the geographic distance between REIT $i$

${ }^{14}$ In an earlier version of this paper we also tried adjusting the distance for the size of the properties and the percentage owned. Assuming the nearby presence of two large properties to be more relevant for risk spillovers than two small properties, we considered both factors as contributing to a measure of "economic importance” rather than just geographical distance. However, we decided against this approach as it dilutes the spatial aspect and prevents an intuitive interpretation of the risk gradient. Moreover, because distance and economic variables are no longer independent, the additivity property of the estimates for the determinants of the spillover coefficients in the nonparametric (nonlinear) and the parametric (linear) part of Figure 6 in subsection 5.1 would no longer hold.

15 As a consequence of this approach the distances between two REITs are not symmetric, i.e. the distance from REIT $i$ to REIT $j$ is not the same as the distance from REIT $j$ to REIT $i$. We make the distance matrix symmetric by taking the averages between both REIT’s distances. 
and REIT $j$. To illustrate this mechanism Figure 4 shows the geographical distribution of the properties of two REIT pairs together with their calculated distance. The left graph shows two REITs with properties in very similar locations. The distance between the REITs is estimated to be 9.08 miles, the closest distance in our sample. ${ }^{16}$ The right graph shows two REITs with very long distances between their properties. For this particular example, the spillover estimates between the REITs with the small distance is roughly 11 times larger than the spillovers between the large distance REITs.

$$
<<<\text { Figure } 4 \text { about here }>>>
$$

\section{Estimating Risk Spillovers: The Time-Series Setting}

Our aim in this section is to estimate and quantify the risk spillovers between single REITs. Hence, we do not model the return distribution but instead focus directly on the REIT's daily risk. A risk measure that will be suitable for our approach is the value-at-risk (VaR). The VaR has the appealing property of expressing the risk in only one number. Its intuitive interpretation and regulatory importance has led to general acceptance and wide application for internal and external purposes. ${ }^{17}$ To illustrate the issue Figure 5 shows the VaR of the S\&P U.S. general REIT Index over the time period 06/01/2007 to 03/16/2011 (956 observations). This period contains tranquil market phases as well as the highly volatile phase of the financial crisis which started to become visible in the REIT returns in mid 2008. Like most firms REITs experienced losses and strongly volatile stock returns during this

${ }^{16}$ This distance is still a multiple of the space that is investigated in the foreclosure literature (Lin, Rosenblatt, and Yao, 2009; Harding, Rosenblatt, and Yao, 2009) where the transmission mechanism of spillovers is largely visual.

${ }^{17}$ For an overview on the accuracy of alternative VaR methods see Lu, Wu, and Ho (2009). Liow (2008) analyzes the VaR dynamics of international securitized real estate and stock market returns using extreme value theory (EVT). 
period. This alternation of different periods presents an opportunity to investigate the risk spillovers during different market states.

$$
<<<\text { Figure } 5 \text { about here }>>>
$$

Having defined an adequate risk measure for the single REIT, we need to model the risk spillovers between REITs. Since spillovers are not constant over time but instead change over different states of the market and depend on the financial health of a firm a suitable model needs to incorporate these conditions. Our SDSVaR model (Adams, Füss, and Gropp, 2012), is related to Adrian and Brunnermeier’s (2011) CoVaR approach. Both methods focus on modelling risk spillovers. However, our approach explicitly accounts for the response magnitude of REITs to shocks during changing conditions of financial health. The quantile regression framework that will allow us to do so was inspired by the CAViaR model of Engle and Manganelli (2004).

For our purpose we apply a slightly modified version of the state-dependent sensitivity value-at-risk (SDSVaR) framework. The SDSVaR follows the two-step process of computing a REIT's standard VaR in a first step, and estimating the risk spillovers between two REITs in a second step.

In the first step, we estimate the VaR for each REIT $m$ :

$$
\widehat{\operatorname{VaR}}_{m}=\hat{\mu}_{m, t}+z \hat{\sigma}_{m, t}
$$

with $\hat{\mu}_{m, t}$ as the mean of REIT $m$ at time $t, m=1,2, \ldots, 74$, and $z$ as the $5 \%$ quantile of the standard normal distribution. It has become practice to model $\hat{\sigma}_{m, t}$ by extracting the conditional standard deviation from a GARCH model (Kuester, Mittnik, and Paolella, 2006). This will account for the time-varying volatility of returns and leads to substantial improvements in the sensitivity of the VaR to changes in the return process. ${ }^{18}$ The VaR is

\footnotetext{
${ }^{18}$ For most of our return series volatility responds more strongly to negative return changes than to positive ones. To capture this fact we apply the asymmetric Exponential GARCH(1,1) of Nelson (1991) with a
} 
then the estimated loss of a REIT that, within a given period (usually 1 to 10 days), will be exceeded with a certain probability $\theta$ (usually $1 \%$ or $5 \%$ ):

$$
\operatorname{prob}\left[\operatorname{return}_{t}<-\operatorname{VaR}_{t} \mid \Omega_{t}\right]=\theta
$$

However, this conditional VaR measure only includes the own past return history, i.e. $\Omega_{t}(\operatorname{VaR})=\left\{r_{i, t-1}, r_{i, t-2}, \ldots, r_{i 0}\right\}$, and does not incorporate the additional risk in REIT $i$ caused by REIT $j$ being in distress. Hence, in our SDSVaR approach we expand the information set $\Omega_{t}$ by including also the $\mathrm{VaR}$ of another $\operatorname{REIT} j$ :

$$
\Omega_{t}(\operatorname{SDSVaR})=\left\{r_{i, t-1}, r_{i, t-2}, \ldots, r_{i 0}, V_{a R}\right\}
$$

In the second step, $\widehat{\operatorname{VaR}}_{m}$ now becomes the dependent variable and is modeled by its own lag, the VaR of the REIT from which the spillover originates, and some control variables Z. For instance, in terms of a shock to the VaR of some REIT $j$ causing spillovers to another REIT $i$, the spillover equation is described by

$$
\widehat{\operatorname{VaR}}_{i, t, \theta}=\alpha_{\theta}+\beta_{1, \theta} \widehat{\operatorname{VaR}}_{i, t-1}+\beta_{2, \theta} \widehat{\operatorname{VaR}}_{j, t}+Z_{t}^{\prime} \gamma_{\theta}+\varepsilon_{t} .
$$

The vector of control variables $Z$ includes the absolute price changes of the general U.S. REIT market, the VaR of the Russell 2000 small cap stock index, and an indicator of economic activity. Controlling for the absolute return changes of the general REIT market helps identifying the marginal spillover effect from REIT $j$ and ensures that the coefficient estimate is not instead measuring some general movements in the REIT market. ${ }^{19}$ In a similar conditional $t$-distribution for the error terms. Our VaR model therefore does not require the returns to be normally distributed. Adams, Füss, and Gropp (2012) also computed the VaR series in Equation (1) using the asymmetric slope version of Engle and Manganelli’s (2004) CAViaR model and obtain similar empirical results. Note further that technically the VaR is just a linear function of the volatility so that exactly the same spillover coefficients can be obtained using volatilities. However, we use VaR instead of volatility as the former has a more direct interpretation.

${ }^{19}$ The general REIT market is modeled by its absolute return changes instead of its VaR because of very high correlations between the VaR of the general REIT market and the VaR of most single REITs (correlations 
way, the VaR of the Russell 2000 index captures the risk coming from the general stock market. ${ }^{20}$ Stevenson (2002) examined the volatility spillovers on monthly REIT returns and found small cap and value stocks to be far more relevant for REIT returns than the general S\&P 500 index or growth stocks. ${ }^{21}$ The purpose of the economic activity variable is to control for regional shocks that could cause two REITs with properties located in the same U.S. state to co-move. This variable is measured in monthly frequency for all states that accommodate the porperties of the shock receiving REIT. ${ }^{22}$ Like the general REIT index and the small cap index, the economic activity indicator helps to separate the spillover effects from simple comovements. By including factors that may be correlated with the risk of individual REIT $j$ the control variables also allow for a causal interpretation of the spillover coefficient $\beta_{2, \theta}$.

Equation (4) is estimated in a system of two equations with the second being the equation for $\operatorname{VaR}_{j, t, \theta}$. The method of estimation is two-stage quantile regression. ${ }^{23}$ Although Equation (4) could be easily estimated by OLS, the resulting spillover coefficient would be an estimate for the average risk spillover over the entire period from 06/01/2007 to

generally above 0.9 ). Other control variables that have been found to be insignificant and are thus not included are the 3-month Treasury bill rates, the REIT CDS index, and the VIX volatility index.

${ }^{20}$ Note the analogy to the systemic risk literature (e.g., Acharya et al., 2010; Brownlees and Engle, 2011) where it is emphasized that shocks from one financial institution to another cannot be measured in isolation. Instead, the relationship of the entire financial system has to be controlled for.

${ }^{21}$ Replacing the Russell 2000 small cap index by the Russell 2000 value index leads to qualitatively identical and quantitatively similar empirical results. The same is true if we use the absolute returns of the Russell 2000 index instead of its VaR.

22 This means that economic activity will be only measured for a subset of all U.S. states, depending on the location of the properties of the REIT on the left-hand side of the equation. This approach improves estimation efficiency and helps to avoid linear dependencies. Economic activity is obtained from the FRED database at http://research.stlouisfed.org. For stationarity reasons, it is measured in percentage changes.

${ }^{23}$ Like in TSLS, this method involves a process of constructing appropriate instuments in the first stage. Unlike TSLS, however, it uses quantile regression instead of ordinary least squares in the second stage, See Powell (1983) for the derivation of the statistical properties of this estimator. 
$16 / 03 / 2011$. The advantage of quantile regression however is that we are able to obtain spillover estimates for different quantiles of the dependent variable. Accordingly, we estimate the spillovers conditioning on the financial health of the REIT receiving the spillovers. We can observe how risk spillovers differ when the REIT that receives the spillover is in financial distress (low quantiles of the VaR distribution), during normal times (median of the VaR distribution), or during tranquil periods (high quantile of the VaR distribution). We choose the $12.5 \%$ quantile for the financial distress state, the $50.0 \%$ quantile for the normal state, and the $75.0 \%$ quantile for the tranquil state. ${ }^{24}$ While the median is a natural choice for the normal state and the particular choice for the upper quantile usually has little effect on the results, the lower quantile is more controversial. The $12.5 \%$ is to some degree arbitrary but reflects the trade-off between estimates that are obtained from a few observations with very large weights versus being too far from the lower distribution tail. The quantile is indicated by the index $\theta$ in Equation (4).

A second issue is the possibility of feedback effects. A shock to the VaR of REIT $j$ may spillover to REIT $i$, but does not need to be unidirectional. Instead there could be substantial feedback effects from REIT $i$ back on REIT $j$. This raises the statistical problem of endogeneity that has to be dealt with. ${ }^{25}$ Two-stage quantile regression is suitable for capturing the simultaneity in the VaR spillovers and their quantification during different financial states of the REIT. We identify the system by assuming that the only lag with a direct effect on the $V a R$ of institution $i$ is the autoregressive term $V a R_{i, t-1}$. Hence, for the exclusion restriction to hold we assume that the only reason why $V a R_{j, t-1}$ affects the $V a R$ of institutions $i$ is the

${ }^{24}$ Thus, while the 5\%-quantile of the return distribution is the VaR, low quantiles of the VaR distribution constitute the VaR during times of financial distress. The former is necessary to obtain the desired risk measure, but it is the latter that introduces state dependency into the model.

${ }^{25}$ We make the assumption that single REITs are not large enough in order to have feedback effects on the general REIT index and on the small cap stock index. 
indirect effect through $V_{a R_{j, t}}$. At the same time the coefficients for the own lagged VaR (e.g., $\beta_{1, \theta}$ in Equation (4)) are statistically significant and therefore constitute valid instruments to identify the system (Wooldridge, 1999). ${ }^{26}$ Adapting the methodology from two-stage least squares to our quantile regression setting is rewarded with consistent estimates that account for the fact that the VaRs of interdependent REITs are determined simultaneously. ${ }^{27}$

We estimate the risk spillovers for all combinations of the 74 REITs, i.e. $74 \times 73=5,402$ quantile regressions over three states or a total of 16,206 regressions. Table 1 shows the coefficient estimates of the SDSVaR model. ${ }^{28}$ We summarize the results in each state by showing the descriptive statistics of the four coefficients. ${ }^{29}$

When the REIT receiving the risk spillover experiences calm market returns, the spillover is on average 0.023 (significant in $72.3 \%$ of all cases), i.e. a one percent increase in the VaR of REIT $j$ increases the VaR of REIT $i$ on average by $0.023 \%$. Although this coefficient is significant in most of the regressions, the absolute value is relatively small. This confirms our expectation that the risk coming from spillovers is present at all times, but that it requires a shock to become activated. Hence, risk spillovers cannot be observed during tranquil market periods. During normal market times, the same $1 \%$ increase in the VaR of

${ }^{26}$ Second lag instrument, $\widehat{V a R}_{i, t-2}$, is insignificant and including it has no effect on the results.

${ }^{27}$ Note that in two-stage quantile regression, like in TSLS, each equation is estimated separately. The state of the market is determined by the quantile of the left-hand side variable.

${ }^{28}$ Note that the coefficient standard errors are not only determined by the sampling error in the quantile regression framework but also by the uncertainty within the VaRs themselves which depend on the GARCH coefficients. However, the large number of regressions make bootstrapping impractical so that the fraction of significant parameters in Table 1 is derived from common asymptotic standard errors. We view this drawback to be of minor relevance since the main results in this paper are based on the cross-section of spillover coefficient estimates rather than their standard errors (see section 5).

${ }^{29}$ The intercept and the coefficients for economic activity are suppressed. Economic activity depends on the shock receiving REIT and cannot be easily summarized in one number. However, the majority of economic activity coefficients are insignificant and, more generally, economic activity does not alter the results in Table 1. 
REIT $j$ leads to a $0.047 \%$ response in the $\operatorname{VaR}$ of REIT $i$, a coefficient that although still relatively small, is twice the size of its tranquil market period counterpart. The largest shock responses, however, are observable when REIT returns are highly volatile. If the shock receiving REIT is in financial distress, the same shock leads to a spillover coefficient of $0.128 \%{ }^{30}$ Although this coefficient may appear to be small in absolute terms, it is important to note that relevant variables such as distance, size, and leverage can further increase the spillover coefficient. Furthermore, the coefficient shows the immediate stock market response of that REIT. As we show in section 5.2 below the total response can accumulate over the trading days with a peak at around day 15. Hence, the coefficient size of 0.128 is quite meaningful economically.

Column 3 in Table 1 shows the coefficient for the $t-1$ lag of REIT i's VaR. The VaR appears to be strongly autoregressive with a coefficient that is close but below unity. ${ }^{31}$ The VaR of the Russell 2000 small cap index has a small but positive sign, indicating that an increase in risk of small cap stocks tends to increase the risk of REITs. This coefficient is significant in $20-30 \%$ of all cases. Finally, the last column shows the effect of the absolute return changes in the general REIT index. As expected, changes in returns indicate higher uncertainty in the overall REIT market which leads to a more negative (i.e., increasing) VaR of single REITs. Furthermore, the general REIT market appears to be more relevant in times of financial distress where it is significant in about $80 \%$ of all regressions.

$<<<$ Table 1 about here $>>>$

\footnotetext{
${ }^{30}$ The financial distress period is represented by the $12.5 \%$ quantile of the VaR distribution. The choice for this quantile is to some extent arbitrary. For instance, the spillover coefficient of 0.128 would increase to 0.142 if we had selected the $10 \%$ quantile, and it would decrease to 0.117 for the $15 \%$ quantile. However, the coefficient estimates do not change dramatically and the exact choice of a low quantile has no material impact on our main results.

${ }^{31}$ The autoregressive structure in the $\mathrm{VaR}$ is a result from the well-known serial correlation in daily financial volatility that is captured by the conditional GARCH standard deviation $\sigma_{m, t}$ in Equation (1).
} 


\section{Explaining Risk Spillovers: The Cross-Sectional Setting}

In the previous section we have demonstrated that risk spillovers among single REITs exist and can be substantial, depending on the financial health of the REIT. The focus was thereby on measurement and quantification of spillovers. In contrast to the previous section where risk spillovers were obtained from daily time series of VaR measures, our aim in this section is to identify the main variables that determine risk spillovers over the cross-section of REITs. We are thereby particularly interested in the risk gradient which shows the risk spillover size as a function of geographical distance. We expect risk spillovers to be larger when two REITs have their properties located in the same region. In this case, property values will be affected by local economic shocks that propagate to neighboring regions such as local employment characteristics or land supply restrictions. With increasing distance, we expect risk spillovers to decrease but to stabilize at a positive value. This value reflects linkages, other than distance related, such as pure stock market linkages and financial characteristics of the shock receiving firm. Finally, we are able to explain the variation in risk spillovers through a selection of financial variables that have been found to be relevant in the systemic risk literature (Acharya et al., 2011; Adrian and Brunnermeier, 2011). These factors complement our analysis on the impact of balance sheet variables on risk spillovers of REITs.

\subsection{Empirical Results}

Among our variables to explain risk spillover size we are particularly interested in the risk gradient, the function describing the relationship between spillovers and geographical distance. To allow a maximum amount of flexibility we therefore model the effect of geographical distance non-parametrically while the effects of the balance sheet regressors are 
modelled in the usual parametric way. ${ }^{32}$ Thereby, the fact that geographical distance is unrelated to any of the financial variables in the model allows us to estimate the nonparametric part and the parametric part separately. ${ }^{33}$ Panel A of Figure 6 shows the scatter plot of risk spillovers as a function of distance together with the predicted nonparametric estimate for tranquil, normal, and volatile REIT states. As expected, REITs that are in a state of financial distress experience much higher risk spillovers than during normal or tranquil periods. In addition, risk spillovers are higher among REITs that have their properties located in adjacent regions. For instance, REITs within a 60 miles distance radius have on average 33\% higher risk spillovers than otherwise identical REITs with distances of more than 250 miles. For the REITs with the shortest distance (about 9 miles), risk spillovers are estimated to be roughly 0.18 , i.e. a one percent increase in the value-at-risk of one REIT increases the VaR of another REIT on average by $0.18 \%$. This risk spillover then decreases nonlinearly and spillovers remain basically unchanged for distances of more than 250 miles. The distance of 250 miles therefore seems to mark the border at which the influence of local economic effects ends and only national economic effects and general stock market linkages remain. ${ }^{34}$ The empirical finding supports Dolde and Tirtiroglu $(1997,2002)$ who report that regional proximity plays an important role for transmitting volatility among housing markets, and is closely related to Zhu, Füss, and Rottke (2011), who find substantial co-movements among

${ }^{32}$ For the nonparametric part we use the second order local polynomial regression.

${ }^{33}$ If we include distance in the parametric model the coefficients of distance and squared distance are highly significant but the parameters of all other regressors change only marginally which confirms the validity of our approach.

${ }^{34}$ Our results concerning the size of risk spillovers in the previous section ignored the distance between REITs and therefore can be interpreted as the spillover size for REITs with average distance. As a consequence, the coefficients at which the risk gradient remains flat corresponds to the spillover coefficients from the previous section: $0.023,0.047$, and 0.128 for tranquil, normal, and volatile levels of volatility, respectively. Small differences between the coefficients we obtain in the nonparametric regression and the ones obtained in the time-series section are due to different methodologies and the fact that the risk gradient does not remain exactly flat after 250 miles. 
regions with a distance of less than 250 miles but no evidence for co-movements for distances of more than 750 miles. ${ }^{35}$ Since a nonparametric function yields no coefficient estimates we show the percentage marginal effects at selected points of the function in the right graph of Panel A. For instance, increasing the distance from 10 miles to 11 miles is estimated to reduce the risk spillover by $0.36 \%$. One additional mile at a distance of 100 miles reduces the risk spillover by only $0.27 \%$ while at 250 miles the slope is flat with no effect of an increase in distance.

$<<<$ Figure 6 about here $>>>$

Panel B of Figure 6 shows the coefficient estimates of the linear parametric part which explains risk spillovers by property type and the financial variables obtained from the balance sheets of REITs. As before, we distinguish between the three financial conditions. In these models, property type and the other financial variables enter the regression in categorical form. For instance, the parameter estimate for the property type indicates that, during times of financial distress, risk spillovers between two industrial REITs are on average 0.0356 higher than between two REITs with a different property type. Similarly, compared to REITs with low levels of leverage, medium or highly leveraged REITs are estimated to have risk spillovers that are about 0.0414 to 0.0588 higher which constitutes a large increase in risk sensitivity. ${ }^{36}$ Two other variables that are estimated to have impacts of similar magnitude are

${ }^{35}$ The similarities with the results in Zhu, Füss, and Rottke (2011) are noteworthy since the authors reach this conclusion using a very different methodology.

${ }^{36}$ Perhaps unexpected, the coefficient for high leverage is lower than of the categorical variable medium leverage. This result can be partly explained by the fact that the majority of REITs in our sample underwent a process of substantial deleveraging. For instance, of the 10 REITs that were allocated to the highest $90 \%$ leverage group in 2007, only two were left in 2010 while the other 8 moved to the medium leverage group. On average, deleveraging REITs reduced their leverage by 22\%. We estimated a version of Figure 6 that inludes the amount of deleveraging in percent and an interaction term of deleveraging with leverage itself (not shown but available upon request). In this modified regression, the coefficient for high leverage is higher than the coefficient for medium leverage, as expected. Another finding is that deleveraging tends to increase spillovers. One explanation for this finding would be that REITs were under pressure to reduce the high levels of leverage 
firm size with spillover estimates of 0.0555 for the $10 \%$ largest companies during a volatile market phase, and firms with a high exposure to stock market changes as measured by beta (0.0613 during volatile financial conditions). To a lesser extent, we can also expect larger spillovers from REITs with higher maturity mismatch or market-to-book values. Finally, we control for relevant characteristics on the side of the REIT transmitting the risk by adding fixed effects for this REIT. The REIT fixed effects are an elegant way to control for all relevant variables without having to model them explicitly and they contribute to overall explanatory power. ${ }^{37}$ Property type, the balance sheet regressors, and REIT transmitter fixed effects explain about half of the total variation in risk spillovers. As an example, consider a REIT A during a volatile phase (0.0795) that mainly holds industrial properties (0.0356), has medium leverage (0.0588), large size (0.0555), high maturity mismatch (0.0231), has a high beta (0.0613), and has its properties located within a 9 miles distance radius $(0.18-0.117)$ to another REIT B. In this example, a $1 \%$ increase of the VaR of REIT B is estimated to increase the VaR of REIT A by $0.377 \%$ on average. ${ }^{38}$

\subsection{The Effect of Distance on the Dynamics and Persistence of Risk Spillovers}

The risk spillover estimates from the preceding section marked the responses of REITs within the same day. However, if REITs are in fact interdependent and shocks are persistent it would seem reasonable to expect reactions to the initial shock to last over a longer time

that emerged from the financial crisis. Strong deleveraging thereby might indicate that the levels were pushed well above their target leverage, leaving the REIT more vulnerable to adverse shocks.

${ }^{37}$ In estimations that explicitly include the balance sheet variables for the risk transmitting REIT we find similar variables to be relevant for risk spillovers, notably size. The $R$-squared in this setting is however lower indicating that other variables are important as well. Also note that the data is not a panel so that we cannot add both, balance sheet variables of the transmitting REITs and fixed effects.

${ }^{38}$ Note that the impact of distance from the nonparametric part equals 0.1800 minus 0.117 with the latter being the co-movement size at 250 miles distance which is determined by national economic impacts and stock market linkages. 
period. In this section, we address this issue by presenting impulse response functions that show the dynamic behavior of a system of two REITs in the presence of a one-time shock to one of the REITs. As an example we consider the two companies Essex Property Trust (ESS), a residential REIT, and Kilroy Realty Corporation (KRC), an office REIT. These REITs have their properties located in the same regions and their estimated distance is only about 9 miles. The estimated coefficients for KRC according to Equation (4) are

$$
\begin{aligned}
& \widehat{V a R}_{K R C, t}=0.001+0.751 \cdot \widehat{V a R}_{K R C, t-1}+0.366 \cdot \widehat{V a R}_{E S S, t} \quad \text { (volatile) } \\
& \widehat{V a R}_{K R C, t}=0.000+0.851 \cdot \widehat{V a R}_{K R C, t-1}+0.157 \cdot \widehat{V a R}_{E S S, t} \quad \text { (normal) } \text {. } \\
& \widehat{\operatorname{VaR}}_{K R C, t}=0.000+0.882 \cdot \widehat{\operatorname{VaR}}_{K R C, t-1}+0.091 \cdot \widehat{V a R}_{E S S, t} \quad \text { (tranquil) }
\end{aligned}
$$

For simplicity, the equations in (6a) do not report the coefficients on the control variables of Equation (4) which are exogenous and can be ignored for the estimation of the impulse response functions. As expected, the risk spillovers are high during volatile times and become smaller for more tranquil periods. The corresponding equations for ESS are

$$
\begin{aligned}
& \widehat{V a R}_{E S S, t}=0.002+0.769 \cdot \widehat{V a R}_{E S S, t-1}+0.229 \cdot \widehat{V a R}_{K R C, t} \quad \text { (volatile) } \\
& \widehat{V a R}_{E S S, t}=-0.001+0.850 \cdot \widehat{V a R}_{E S S, t-1}+0.120 \cdot \widehat{V a R}_{K R C, t} \quad(\text { normal }) . \\
& \widehat{V a R}_{E S S, t}=0.000+0.878 \cdot \widehat{V a R}_{E S S, t-1}+0.077 \cdot \widehat{V a R}_{K R C, t} \quad \text { (tranquil) }
\end{aligned}
$$

In contrast to correlation coefficients which are symmetric by construction, the spillover coefficients are directional and asymmetric. In particular, a shock in ESS is estimated to provoke a larger response in KRC than an identical shock going in the other direction.

The lower left graph in Figure 7 shows the response of Kilroy to a one time shock from Essex for each financial state. Because of the generally high persistence in the volatility and thus in the SDSVaRs, responses accumulate and peak at about 15 trading days after the shock. If the shock receiving REIT (KRC) is in a normal or volatile financial condition, the responses are large and stay in the system for several months. 
We contrast these strong risk linkages with a hypothetical situation, in which the distance between the two REITs is increased to 500 miles but all other characteristics are held constant. This approach highlights the impact of geographical proximity not only on the immediate response size but also on the short-term dynamics in the system. We use the nonparametric regression approach from the previous section which predicts that spillover coefficients in Equation (6a) would decrease to 0.25 , 0.10, and 0.05 for volatile, normal, and tranquil states, respectively. Similarly, we replace the spillover coefficients in Equation (6b) by their lower estimates of $0.16,0.07$, and 0.05 . The other coefficients are assumed to remain unchanged. The lower right graph in Figure 7 shows the responses for this counterfactual situation. The two REITs are now no longer linked by local economic conditions but only through stock market changes and their individual REIT characteristics. The response to changes in risk and the persistence to those changes are therefore significantly lower. After Essex experiences a one-time shock, the responses die out quickly and vanish entirely after about 40 days.

The empirical results from this example highlight how regional proximity, in which spillover size is only about $58 \%$ higher than in the counterfactual long-distance case has substantial impact on both, spillover size and persistence.

$$
<<<\text { Figure } 7 \text { about here }>>>
$$

\section{Conclusion}

In this paper, we investigate the impact of geographical proximity on the risk spillovers of REITs. We obtain a distance measure by comparing the latitude and longitude information of the properties owned by the REITs. The risk gradient, a measure of spillover size as a function of geographical distance indicates large spillovers for REITs that have their properties in close distance. This function decreases nonlinearly and is flat for distances of 
more than 250 miles. Within a radius of 50 miles, local economic linkages cause risk spillovers to be on average 43\% higher than spillovers among REITs that are more than 250 miles apart. We interpret this 250 miles range as the reach of local economic influence. Among the firm characteristics that can explain the cross-sectional variation in risk spillovers we find leverage, market beta, and company size to be the main drivers of spillover size.

A growing literature in the area of contagion and systemic risk indicates that spillovers are particularly relevant for the tails of a risk distribution, i.e. when one or more firms are in a state of financial distress. We demonstrate that risk spillovers depend on the financial conditions of the REIT responding to the spillover. While small during tranquil periods, risk spillovers can be substantial when the responding REIT is in financial distress.

Our empirical findings highlight the importance of geographical diversification in a portfolio of REITs. If REITs are in close proximity to each other, they may individually appear to be geographically diversified but the portfolio as a whole is not. The portfolio may be exposed to spillover risk that remains hidden in calm market periods but becomes activated by a financial shock. Hence, geographic diversification should be accompanied by a measure of geographic distance between REITs. 
Table A1: List of REITs by Property Type

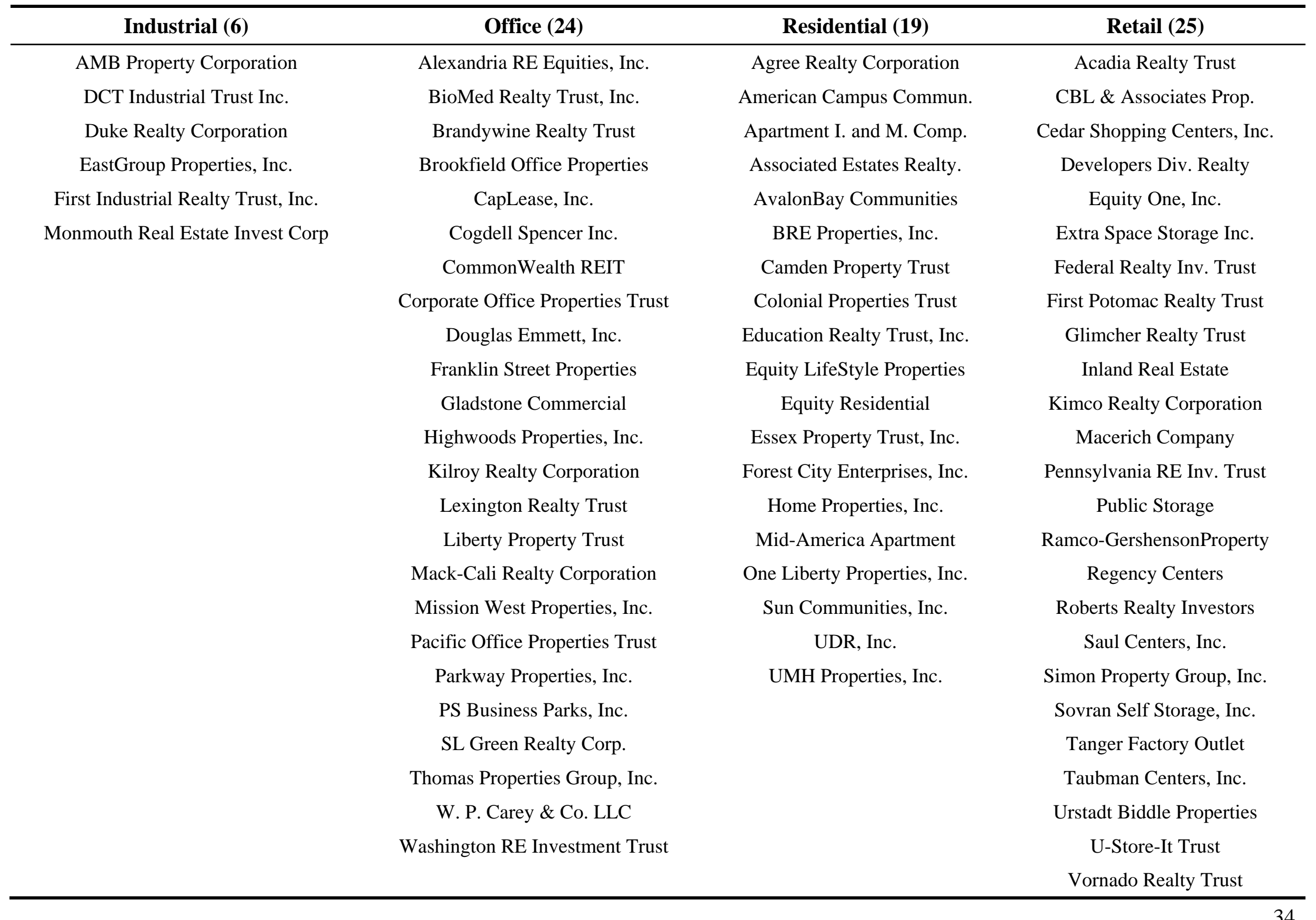




\section{References}

Abraham, J., Hendershott, P., 1996. Bubbles in Metropolitan Housing Markets. Journal of Housing Research 7, 191-207.

Acharya, V., Pedersen, L.H., Philippon, T., Richardson, M., 2010. Measuring Systemic Risk. FRB of Cleveland Working Paper No.10-02.

Adams, Z., Füss, R., Gropp, R., 2012. Spillover Effects among Financial Institutions: A State-Dependent Sensitivity Value-at-Risk (SDSVaR) Approach. Journal of Financial and Quantiative Analysis, forthcoming.

Adrian, T., Brunnermeier, M.K., 2011. CoVaR. Working Paper, Princeton University, September 15.

Alexander, C., Barrow, M., 1994. Seasonality and Cointegration of Regional House Prices in the UK. Urban Studies 31(10), 1667-1689.

Bae, K., Karolyi, G.A., Stulz, R., 2003. A New Approach to Measuring Financial Contagion. Review of Financial Studies 16, 717-763.

Bailey, W., Stulz, R.M., 1990. Benefits of International Diversification: The Case of Pacific Basin Stock Markets. The Journal of Portfolio Management 17, 47-61.

Bekaert, G., Harvey, C.R., Ng, A., 2005. Market Integration and Contagion. Journal of Business 78(1), 39-69.

Benveniste, L., Capozza, D.R., Seguin P.J., 2001. The Value of Liquidity. Real Estate Economics 29(4), 633-660.

Brounen, D., Ling, D.C., Porras Prado, M., 2012. Short Sales and Fundamental Value: Explaining the REIT Premium to NAV. Working Paper, available at SSRN: http://ssrn.com/abstract=1469454.

Brownlees, C.T., Engle, R.F., 2011. Volatility, Correlation and Tails for Systemic Risk Measurement. Working Paper, available at SSRN: http://ssrn.com/abstract=1611229

Brunnermeier, M.K., Pedersen, L.H., 2009. Market Liquidity and Funding Liquidity. The Review of Financial Studies 22(6), 2201-2238.

Capazzo, D.R., Lee, S., 1995. Property Type, Size and REIT Value. Journal of Real Estate Research 10(4), 363-379.

Capazzo, D.R., Seguin, P.J., 1999. Why Focus Matters. Real Estate Finance 17(4), 7-15.

Capazzo, D.R., Seguin, P.J., 1999. Focus, Transparency and Value. Real Estate Economics 27(4), 587-619.

Chen, Z., Liow, K.H., 2006. Mean and Volatility Spillovers across Major Real Estate Markets. Working Paper, National University of Singapore.

Chen, J., Peiser, R., 1999. The Risk and Return Characteristics: 1993-1997. Real Estate Finance 16(1), 61-68.

Chiang, K., Lee, M., 2002. REITs in the Decentralised Investment Industry. Journal of Property Investment and Finance 20, 496-512.

Chiang, K.C.H., 2010. On the Comovement of REIT Prices. Journal of Real Estate Research 32(2), 187-200. 
Cici, G., Corgel, J., Gibson, S., 2011. Can Fund Manager Select Outperforming REITs? Examining Fund Holdings and Trades. Real Estate Economics 39(3), 455-486.

Clayton, J., MacKinnon, G., 2001. Explaining the Discount of NAV to REIT Pricing: Noise or Information? RERI Working Paper, January

Clayton, J., MacKinnon, G., 2002. Departures from NAV in REIT Pricing: The Private Real Estate Cycle, the Value of Liquidity and Investor Sentiment. Working Paper.

Collett, D., Lizieri, C., Ward, C., 2003. Timing and the Holding Periods of Institutional Real Estate. Real Estate Economics 31(2), 205-222.

Cotter, J., Stevenson, S., 2006. Multivariate Modeling of Daily REIT Volatility. Journal of Real Estate Finance and Economics 32, 305-325.

Coulson, N.E., Liu, C.H., Villupuram, S.V., 2010. Urban Economic Base as a Catalyst for Movements in Real Estate Prices. Working Paper Series, Cornell University.

Cromwell, B.A., 1992. Does California Drive the West? An Econometric Investigation of Regional Spillover. Economic Review of the Federal Reserve Bank of San Francisco 2, 13-23.

DiPasquale, D., Wheaton, W.C., 1996. Urban Economics and Real Estate Markets, Harlow UK: Prentice-Hall.

Dolde, W., Tirtiroglu, D., 1997. Temporal and Spatial Information Diffusion in Real Estate Price Changes and Variances. Real Estate Economics 25(4), 539-565.

Dolde, W., Tirtiroglu, D., 2002. House Price Volatiliy Changes and their Effects. Real Estate Economics 30(1), 41-66.

Eichholtz, P., Hoesli, M., MacGregor, B.D., Nanthakumaran, N., 1995. Real Estate Portfolio Diversification by Property Type and Geographical Region in the United Kingdom and the United States. Journal of Property Finance 6(3), 39-59.

Elyasiani, E., Mansur, I., Wetmore, J.L., 2010. Real Estate Risk Effects on Financial Institutions' Stock Return Distribution: a Bivariate GARCH Analysis. Journal of Real Estate Finance and Economics 40, 89-107.

Engle, R.F., Manganelli, S., 2004. CAViaR: Conditional Autoregressive Value at Risk by Regression Quantiles. Journal of Business and Economic Statistics 22(4), 367-381.

Fisher, J. D., Young, M. S., 2000. Institutional Property Tenure: Evidence from the NCREIF Database. Journal of Real Estate Portfolio Management 6(4), 327-338.

Glaeser, E.L., Gyourko, J., Saiz, A., 2008. Housing Supply and Housing Bubbles. Journal of Urban Economics 64, 198-217.

Glascock, J.L., Lu, C., So, R.W., 2000. Further Evidence on the Integration of REIT, Bond, and Stock Returns. Journal of Real Estate Finance and Economics, 20(2), 177-194.

Goetzmann, W.N., Li, L., Rouwenhorst, K.G., 2005. Long-Term Global Market Correlations. Journal of Business 78(1), 1-38.

Gordon, I., 1990. Housing and Labor Market Constraints to Migration across the North-South Divide, in Ermisch, J., (Eds.). Housing and the National Economy, Aldershot

Griffin, J.M., Lemmon, M.L., 2002. Book-to-Market Equity, Distress Risk, and Stock Returns. The Journal of Finance 57(5), 2317-2336. 
Grissom, T.V., Hartzell, D.J., Liu, C.H., 1987. An Approach to Industrial Real Estate Market Segmentation and Valuation Using the Arbitrage Pricing Paradigm. Journal of American Real Estate and Urban Economics Association (AREUEA) 15(3), 199-219.

Gyourko, J., 2004. Real Estate Returns in Public and Private Markets. Wharton Real Estate Review, Spring Issue.

Gyourko, J., 2009. Understanding Commercial Real Estate: Just how Different from Housing is it? NBER Working Paper Series 14708, Cambridge MA, February.

Gyourko, J., Keim, D., 1992. What does the Stock Market tell us about Real Estate Returns? AREUEA Journal 20(3), 457-485.

Harding, J.P., Rosenblatt, E., Yao, V.W., 2009. The Contagion Effect of Foreclosed Properties. Journal of Urban Economics 66, 164-178.

Hartzell, D.J., Hekman, J., Miles, M., 1986. Diversification Categories in Investment Real Estate. Journal of American Real Estate and Urban Economics Association (AREUEA) 14(2), 230-254.

Hartzell, D.J., Shulman, D., Wurtzebach, C., 1987. Refining the Analysis of Regional Diversification for Income Producing Real Estate. Journal of Real Estate Research 2(2), 85-95.

Hoesli, M., Reka, K., 2011. Volatility Spillovers, Comovements and Contagion in Securitized Real Estate Markets. Swiss Finance Institute Research Paper Series No. 10-40.

Immergluck, D., Smith, G., 2006. The External Costs of Foreclosure: The Impact of SingleFamily Mortgage Foreclosures on Property Values. Housing Policy Debate 17(1), 5779.

Ioannides, Y.M., 2003. Interactive Property Valuations. Journal of Urban Economics 53, 145170.

Kuester, K., Mittnik,S., Paolella, M.S., 2006. Value-at-Risk Prediction: A Comparison of Alternative Strategies. Journal of Financial Econometrics 4(1), 53-809.

Lakonishock, J., Shleifer, A., Vishny, R.W., 1994. Contrarian Investment, Extrapolation, and Risk. The Journal of Finance 49(5), 1541-1578.

Lee, S., Devaney, S.P., 2007. The Changing Importance of Sector and Regional Factors in Real Estate Returns: 1987-2002. Journal of Property Research 24(1), 55-69.

Lin, Z., Rosenblatt, E., Yao, V.W., 2009. Spillover Effects of Foreclosure on Neighborhood Property Values. Journal of Real Estate Finance and Economics 38(4), 387-407.

Liow, K.H. ,2008. Extreme Returns and Value at Risk in International Securitized Real Estate Markets. Journal of Property Investment and Finance 26(5), 418-446.

Lu, C., Wu, S.-C., Ho, L.-C., 2009. Applying VaR to REITs: A Comparison of Alternative Methods. Review of Financial Economics 18(2), 97-102.

MacDonald, R., Taylor, M.P., 1993. Regional House Prices in Britain. Scottish Journal of Political Economy 40(1), 43-55.

Malizia, E., Simmons, R., 1991. Comparing Regional Classification for Real Estate Portfolio Diversification. Journal of Real Estate Research 6(1), 53-77.

Malpezzi, S., 1999. A Simple Error Correction Model of House Prices. Journal of Housing Economics 8, 27-62. 
Marshall, B., Nguyen, N., Visaltanachoti, N., 2012. Commodity Liquidity Measurement and Transaction Costs. Review of Financial Studies 25(2), 599-638.

Meen, G., 1999. Regional House Prices and the Ripple Effect: A New Interpretation. Housing Studies 14(6), 733-753.

Miao, H., Ramchander, S., Simpson, M.C., 2011. Return and Volatility Transmission in U.S. Housing Markets, Real Estate Economics, forthcoming.

Miles, M., McCue, T., 1982. Historic Returns and Institutional Real Estate Portfolios. Journal of American Real Estate and Urban Economics Association (AREUEA) 10(2), 184199.

Miles, M., McCue, T., 1984. Commercial Real Estate Returns. Journal of American Real Estate and Urban Economics Association (AREUEA) 12(2), 355-377.

Mühlhofer, T., 2011. They Would if They Could: Assessing the Bindingness of the Property Holding Constraints for REITs, Working Paper, Kelley School of Business, Indiana University, August 15.

Nelson, D.B., 1991. Conditional Heteroskedasticity in Asset Returns: A New Approach. Econometrica 59(2), 347-370.

Patel, K., Pereira, R.A.M.G., Zavodov, K.V., 2009. Mean Reversion in REITs Discount to NAV \& Risk Premium. Journal of Real Estate Finance and Economics 39(3), 229-247.

Pollakowski, H.O., Ray, T.S., 1997. Housing Price Diffusion Patterns at Different Aggregation Levels: An Examination of Housing Market Efficiency. Journal of Housing Research 8(1), 107-124.

Powell, J.L., 1983. The Asymptotic Normality of Two-Stage Least Absolute Deviations Estimators. Econometrica 51(5),1569-1575.

Roback, J., 1982. Wages, Rents, and the Quality of Life. Journal of Political Economy 90(4), 1257-78.

Rosen, S., 1979. Wage-Based Indexes of Urban Quality of Life. In Current Issues in Urban Economics, edited by P. Mieszkowski and M. Straszheim. Baltimore: Johns Hopkins University Press.

Solnik, B.H., Boucrelle, C., Le Fur, Y., 1996. International Market Correlation and Volatility, Financial Analysts Journal 52(5), 17-34.

Stevenson, S., 2002. An Examination of Volatility Spillovers in REIT Returns. Journal of Real Estate Portfolio Management 8, 229-283.

SeungHan, R., Ziobrowski, A.J., 2011. Does Focus Really Matter? Specialized vs. Diversified REITs. Journal of Real Estate Finance and Economics 42(1), 68-83.

Sun, L., Titman, S., Twite G., 2013. REIT and Commercial Real Estate Returns: A Post Mortem of the Financial Crisis. Working Paper, May.

Wooldridge, J.M., 1999. Econometric Analysis of Cross Section and Panel Data. The MIT Press.

Zhu, B., Füss, R., Rottke, N., 2011. Spatial Linkages in Returns and Volatilities among U.S. Regional Housing Markets, Real Estate Economics, forthcoming. 
Table 1: SDSVaR Coefficient Estimates for Different States of Distress (06/2007-03/2011)

Tranquil

\begin{tabular}{|c|c|c|c|c|}
\hline & Spillover & Lag & VaR Russell & Ret. REIT Ind. \\
\hline First Quartile & 0.0052 & 0.9064 & -0.0019 & -0.0039 \\
\hline Mean & 0.0232 & 0.9188 & 0.0036 & -0.0015 \\
\hline Third Quartile & 0.0346 & 0.9397 & 0.0095 & 0.0014 \\
\hline Standard Deviation & 0.0251 & 0.0315 & 0.0092 & 0.0046 \\
\hline Skewness & 1.5459 & -2.0563 & -0.3160 & -0.8838 \\
\hline Excess Kurtosis & 2.9081 & 6.3569 & 1.1803 & 2.9147 \\
\hline \% Significant & 72.29 & 100 & 21.83 & 26.43 \\
\hline \multicolumn{5}{|c|}{ Normal } \\
\hline & Spillover & Lag & VaR Russell & Ret. REIT Ind. \\
\hline First Quartile & 0.0149 & 0.9018 & -0.0033 & -0.0081 \\
\hline Mean & 0.0474 & 0.9221 & 0.0065 & -0.0044 \\
\hline Third Quartile & 0.0710 & 0.9509 & 0.0163 & -0.0008 \\
\hline Standard Deviation & 0.0455 & 0.0380 & 0.0158 & 0.0069 \\
\hline Skewness & 1.0735 & -1.2358 & -0.1159 & 0.2012 \\
\hline Excess Kurtosis & 1.2886 & 1.6168 & 2.3052 & 1.3672 \\
\hline \% Significant & 86.6 & 100 & 29.8 & 40.5 \\
\hline \multicolumn{5}{|c|}{ Volatile } \\
\hline & Spillover & Lag & VaR Russell & Ret. REIT Ind. \\
\hline First Quartile & 0.0539 & 0.8836 & -0.0258 & -0.0491 \\
\hline Mean & 0.1282 & 0.9325 & 0.0037 & -0.0363 \\
\hline Third Quartile & 0.1893 & 0.9924 & 0.0287 & -0.0197 \\
\hline Standard Deviation & 0.0948 & 0.0801 & 0.0504 & 0.0260 \\
\hline Skewness & 0.7421 & -0.7472 & -0.0610 & -1.0860 \\
\hline Excess Kurtosis & 0.1696 & 0.3403 & 5.2277 & 3.1916 \\
\hline \% Significant & 87.8 & 100 & 24.9 & 77.9 \\
\hline
\end{tabular}

This table shows descriptive statistics for 16,206 quantile regression estimates over the time period 06/01/2007 through 03/16/2011 (956 Obs.). We distinguish between three states of financial health (tranquil, normal, and volatile). Market states are measured by the 75\%-, 50\%-, and the $12.5 \%$-quantile of the value-at-risk distribution of the responding REIT, respectively.The value-at-risk of REIT $i$ is regressed on its own lagged value (Lag) and the VaR of REIT $j$ (Spillover) controlling for the absolute returns of the S\&P (General) U.S. REIT Index (Ret. REIT Ind.) and the VaR of the Russell 2000 Small Cap Index (VaR Russell):

$$
\widehat{\operatorname{VaR}}_{i, t, \theta}=\alpha_{\theta}+\beta_{1, \theta} \widehat{\operatorname{VaR}}_{i, t-1}+\beta_{2, \theta} \widehat{\operatorname{VaR}}_{j, t}+\beta_{3, \theta} \widehat{\operatorname{VaR}}_{\text {Small.Cap }, t}+\beta_{4, \theta}\left|\operatorname{Ret}_{\text {REIT.Index }, t}\right|+\varepsilon_{t} .
$$


Figure 1: Risk Sources and Transmission Channels

\section{Panel A: Sources of Risk Spillovers}

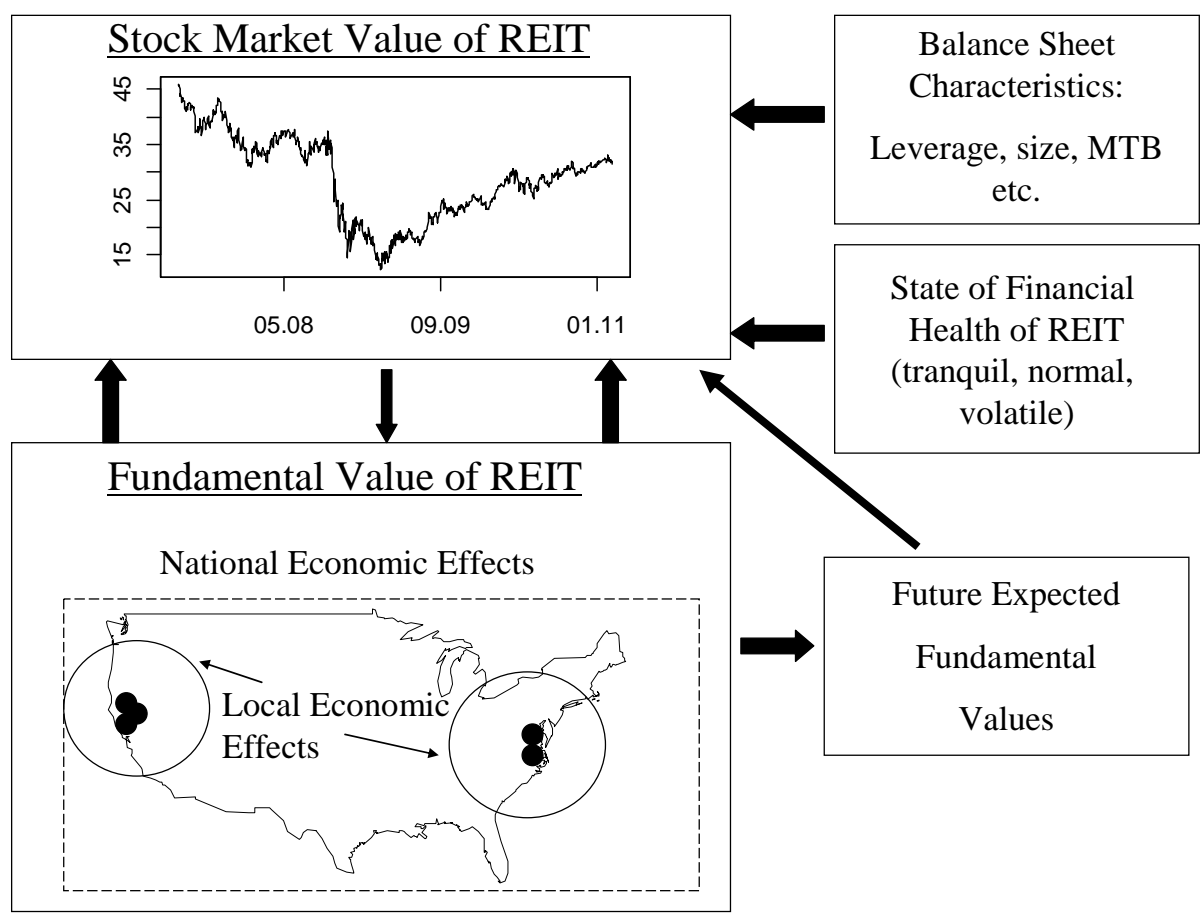

\section{Panel B: The Role of Distance for Risk Spillovers}

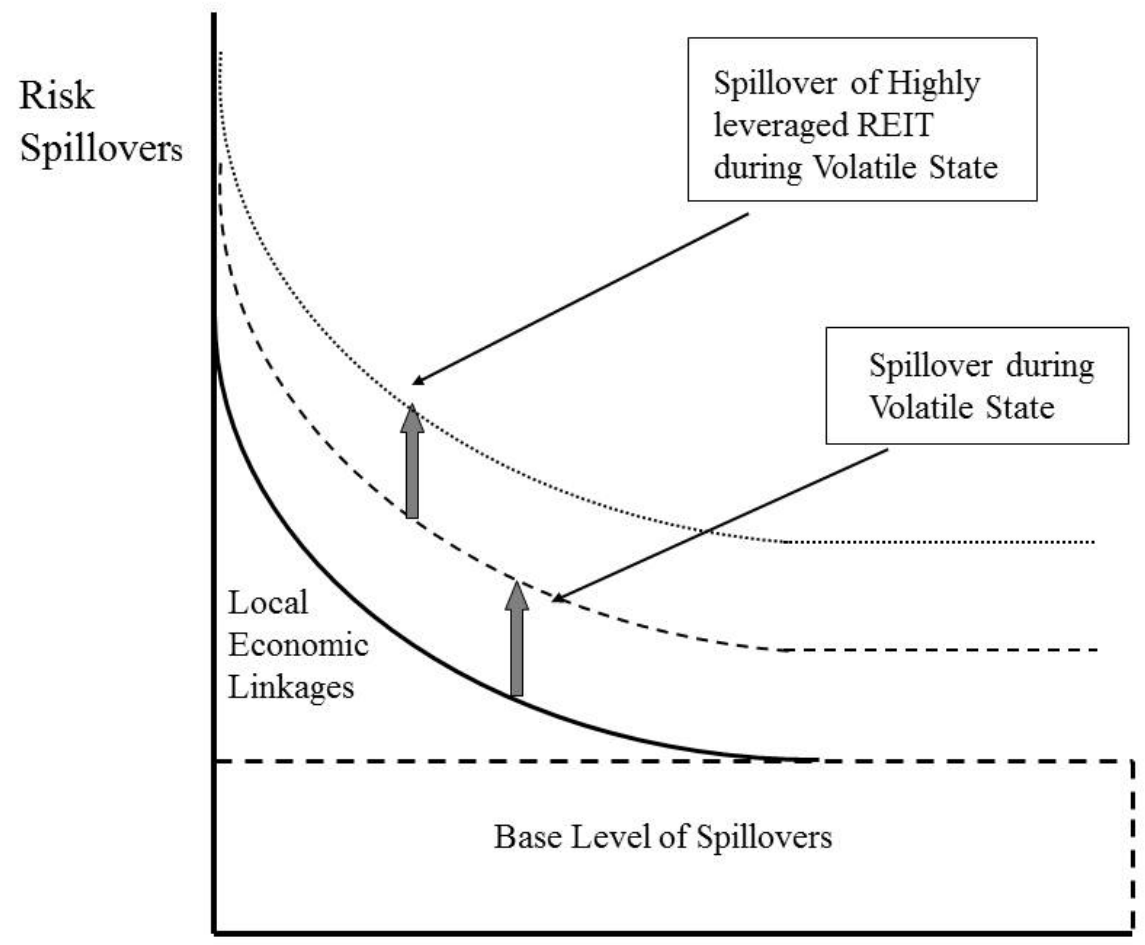

Distance between REIT holdings 
Figure 2: Descriptive Statistics and Location of Properties

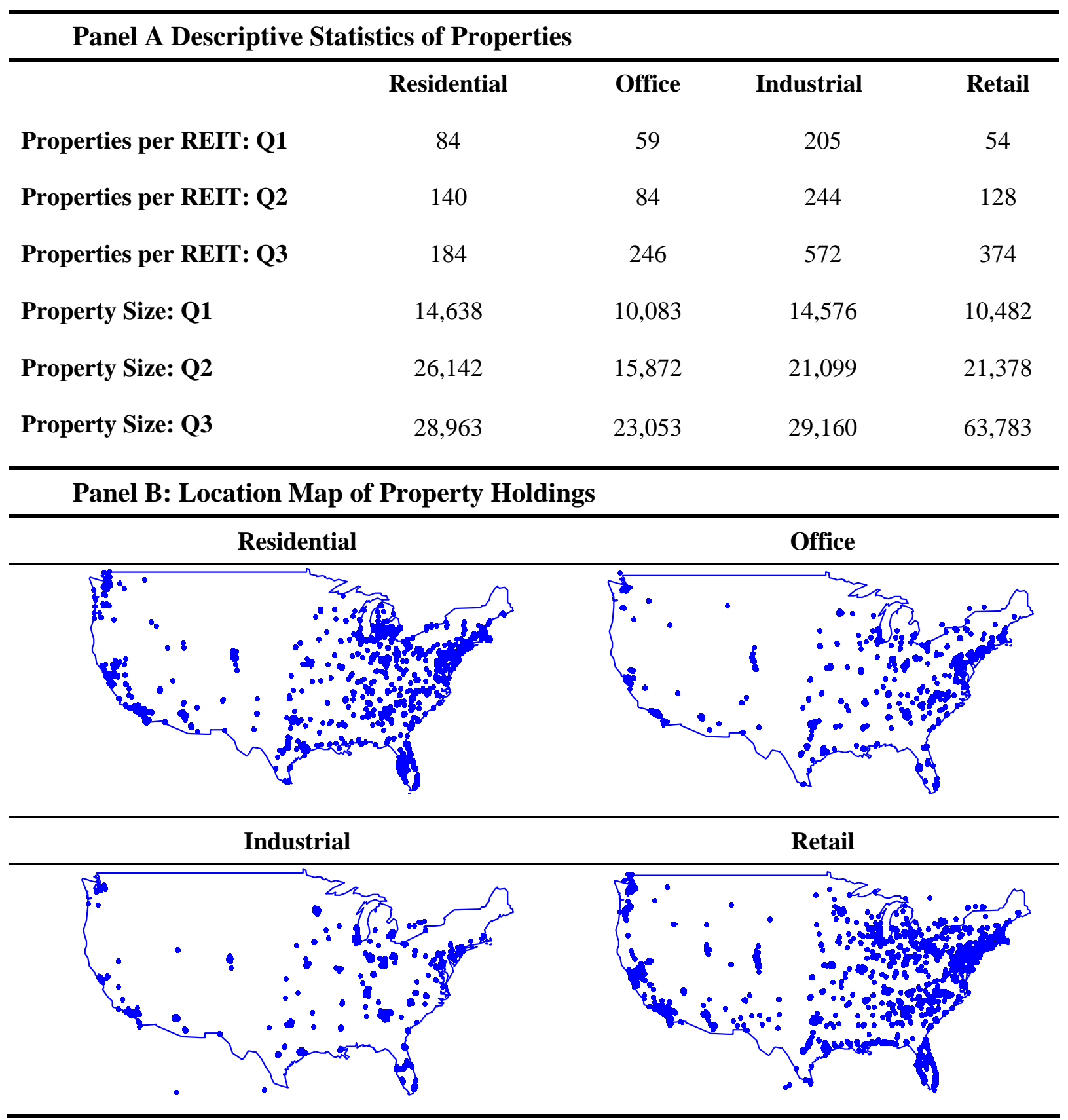

Panel A shows the number of properties owned per REIT as well as the typical property size in sqm. For instance, the median number of properties for residential REITs is 140 . Only $25 \%$ of office REITs have properties with more than 23,053 sqm in size. Panel B shows the location of the properties by property type. 
Figure 3: Descriptive Statistics and Distribution of Regressors

\begin{tabular}{lcccccc}
\hline \multicolumn{7}{l}{ Panel A: Descriptive Statistics for Selected Regressors } \\
& Q.25 & Median & Q.75 & Std. Dev. & Skewness & Kurtosis \\
\hline Leverage & 2.36 & 2.71 & 3.25 & 1.80 & 2.63 & 8.03 \\
Maturity Mismatch [\%] & 3.86 & 6.56 & 11.03 & 6.75 & 1.57 & 2.35 \\
Market-to-Book & 0.90 & 1.44 & 1.87 & 1.11 & 2.75 & 10.70 \\
Size x 10 & 1,497 & 2,857 & 6,123 & 6,398 & 3.50 & 15.69 \\
Market Beta & 0.62 & 0.83 & 0.95 & 0.38 & 0.37 & 0.63 \\
\hline Panel B: Distribution of Regressor Values: Leverage & & & \\
\hline
\end{tabular}

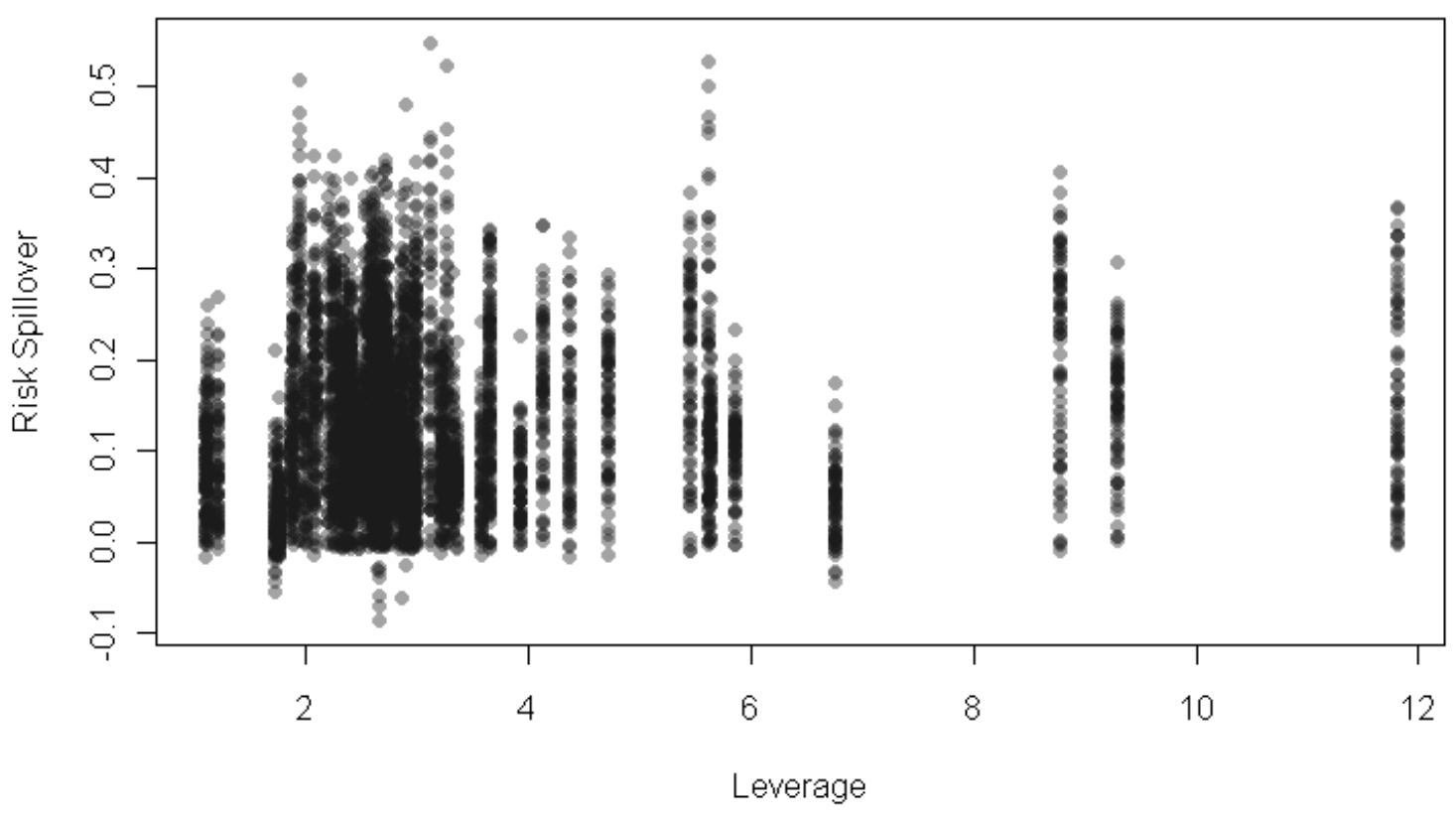

Panel A shows the descriptive statistics of the balance sheet variables used as regressors to explain the size of risk spillovers. Leverage is computed as total assets divided by total book equity, maturity mismatch is given in percent and defined as (short-term debt plus debt due this financial year minus cash) divided by total liabilities and size is approximated by total enterprise value (company's debt plus equity) and is given in billions of U.S. dollars; market-to-book is defined as REIT's market capitalization divided by it's total book value and market beta is the REIT's market sensitivity to S\&P 500 Composite Index. Panel B shows the distribution of the leverage within our sample which highlights the need to treat the financial variables as categorical instead of continues variables. Regressing each of the 74 REITs on the other 73 REITs leads to the observed scattering along a line of repeated leverage values. 
Figure 4: Location of Properties and Estimated Distance between REITs

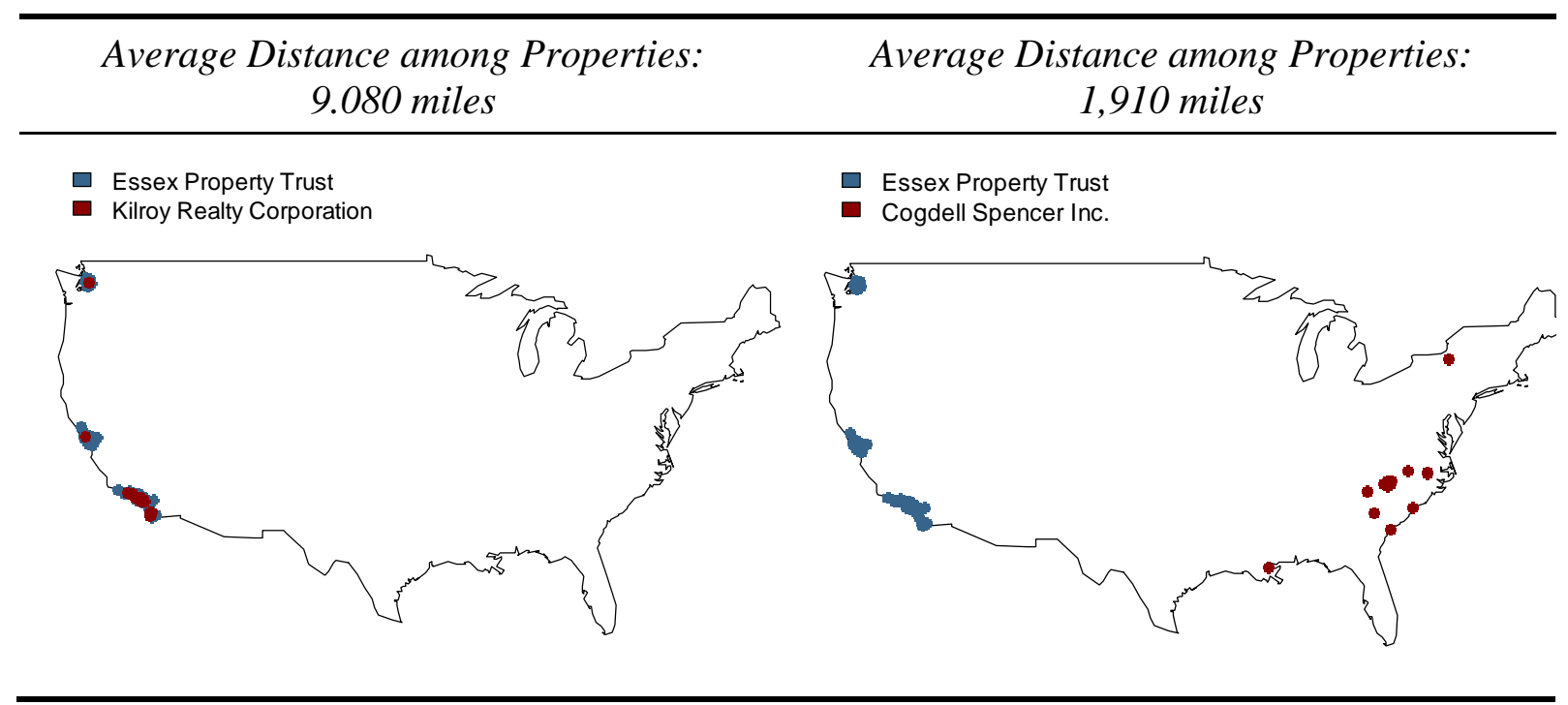

This figure shows in the left graph the geographical distribution of the properties of Essex Property Trust and Kilroy Realty Corporation with properties in very similar locations. The right graph shows the distance between Essex Propety Trust and Cogdell Spencer Inc. with a very long distances between their properties. 
Figure 5: Daily Value-at-Risk of the U.S. REIT Market

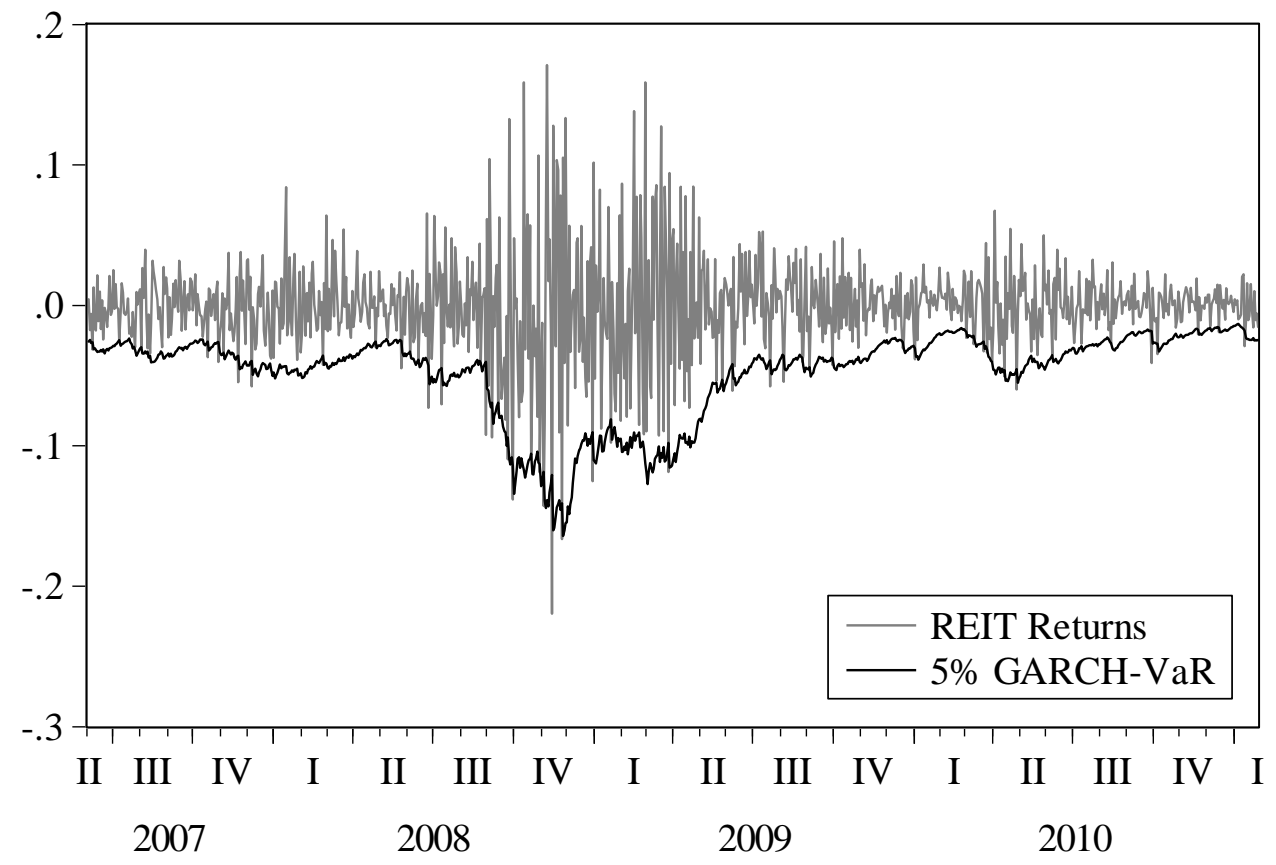

This figure shows the VaR of the S\&P U.S. (General) REIT Index over the time period 06/01/2007 to 03/16/2011 including 956 return observations. The 5\%-GARCH-VaR is based on asymmetric Exponential GARCH(1,1) process with a conditional $t$-distribution for the error terms. 


\section{Panel A: Non-Linear Part}

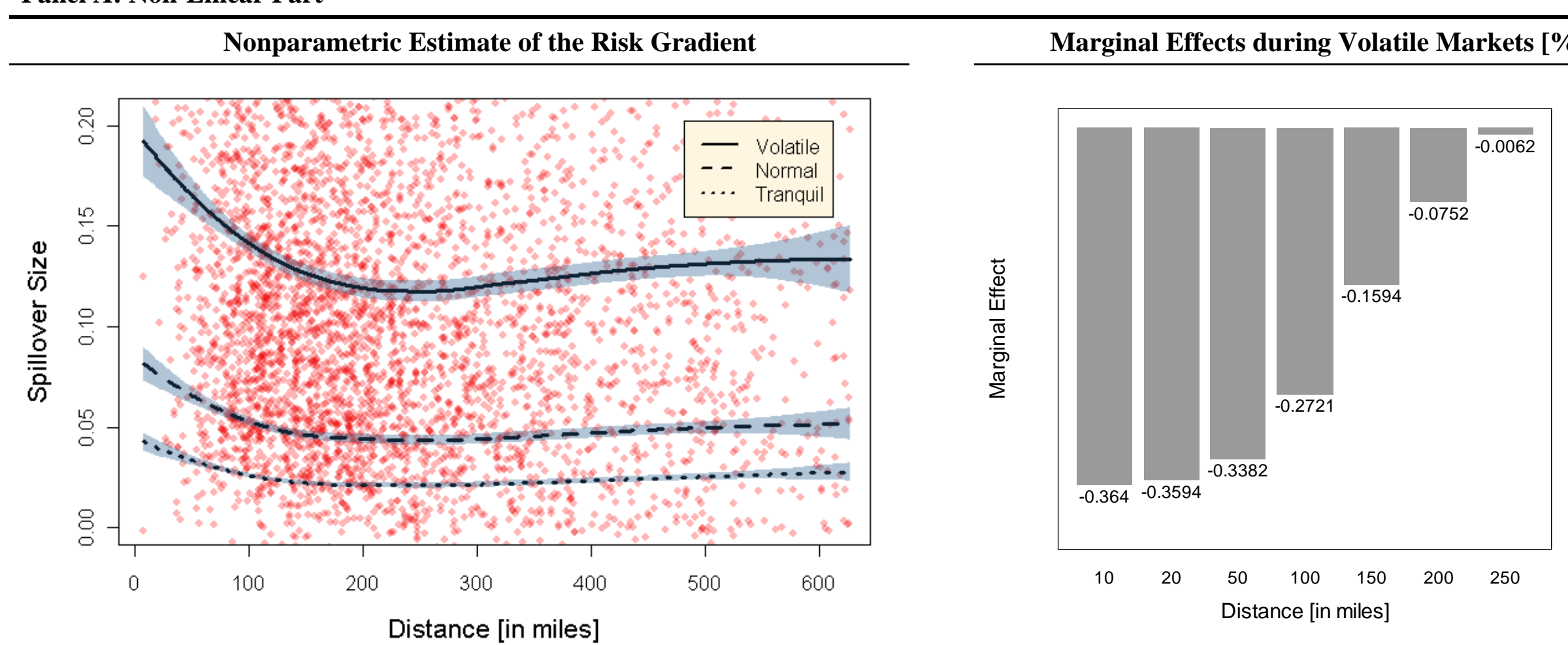

\section{Panel B: Linear Part}

\begin{tabular}{|c|c|c|c|c|c|c|c|}
\hline & Volatile & Normal & Tranquil & & Volatile & Normal & Tranquil \\
\hline Constant & $0.0795^{* * *}$ & $0.0106^{*}$ & 0.0055 & Med. Size & $0.013^{* * *}$ & $0.02^{* * *}$ & $0.0154^{* * *}$ \\
\hline Industrial & $0.0356^{* *}$ & 0.0006 & 0.0017 & High Size & $0.0555^{* * *}$ & $0.053^{* * *}$ & $0.0372^{* * *}$ \\
\hline Office & -0.0005 & $0.0039^{* *}$ & 0.0006 & Med. МТВ & 0.0043 & $0.0126^{* * *}$ & $0.006^{* * *}$ \\
\hline Residential & $0.0186^{* * *}$ & $0.0196^{* * *}$ & $0.0131^{* * *}$ & High MTB & -0.0006 & 0.0031 & 0.0013 \\
\hline Retail & $-0.0208^{* * *}$ & $-0.0167^{* * *}$ & $-0.0082^{* * *}$ & Med. Beta & $0.041^{* * *}$ & $0.0167^{* * *}$ & $0.007^{* * *}$ \\
\hline Med. Leverage & $0.0588^{* * *}$ & $0.0275^{* * *}$ & $0.0142^{* * *}$ & High Beta & $0.0613^{* * *}$ & $0.0294^{* * *}$ & $0.0142^{* * *}$ \\
\hline
\end{tabular}




\begin{tabular}{lccccccc} 
High Leverage & $0.0414^{* * *}$ & $0.0224^{* * *}$ & $0.0056^{* * *}$ & Transmiter F.E. & Yes & Yes & Yes \\
Med. Mat. Mis. & 0.003 & $0.0087^{* * *}$ & $0.0024^{* * *}$ & F-Statistic & 61.203 & 43.846 & 46.806 \\
High. Mat. Mis. & $0.0231^{* * *}$ & $-0.0061^{* * *}$ & $-0.0045^{* * *}$ & Adj. R-Squared & 0.529 & 0.496 & 0.46 \\
\hline
\end{tabular}

This table shows the coefficients of various balance sheet regressors that enter the model in categorical form. The dependent variable is the spillover coefficient during three financial states (tranquil, normal, and volatile). Panel A presents the estimation results of the non-parametric regression with risk spillovers as a function of distance together with the nonparametric estimate for tranquil, normal, and volatile REIT states. Panel B shows the coefficient estimates of the linear parametric part for the three financial market states. The intercept is the spillover estimate for a small REIT with a diversified sector focus that has low leverage, low maturity mismatch, low MTB, and low market beta and that receives a risk spillover from a REIT with a different property type. Transmitter fixed effects control for relevant characteristics of the REITs on the right hand side from which the risk is propagated to the left hand side of our SDSVaR equation. The total number of observations is 5,402 for each financial state. Estimates for statistical significance are based on a heteroscedasticity-consistent coefficient covariance matrix. 
Figure 7: Impulse Response Functions for Close and Distant Properties

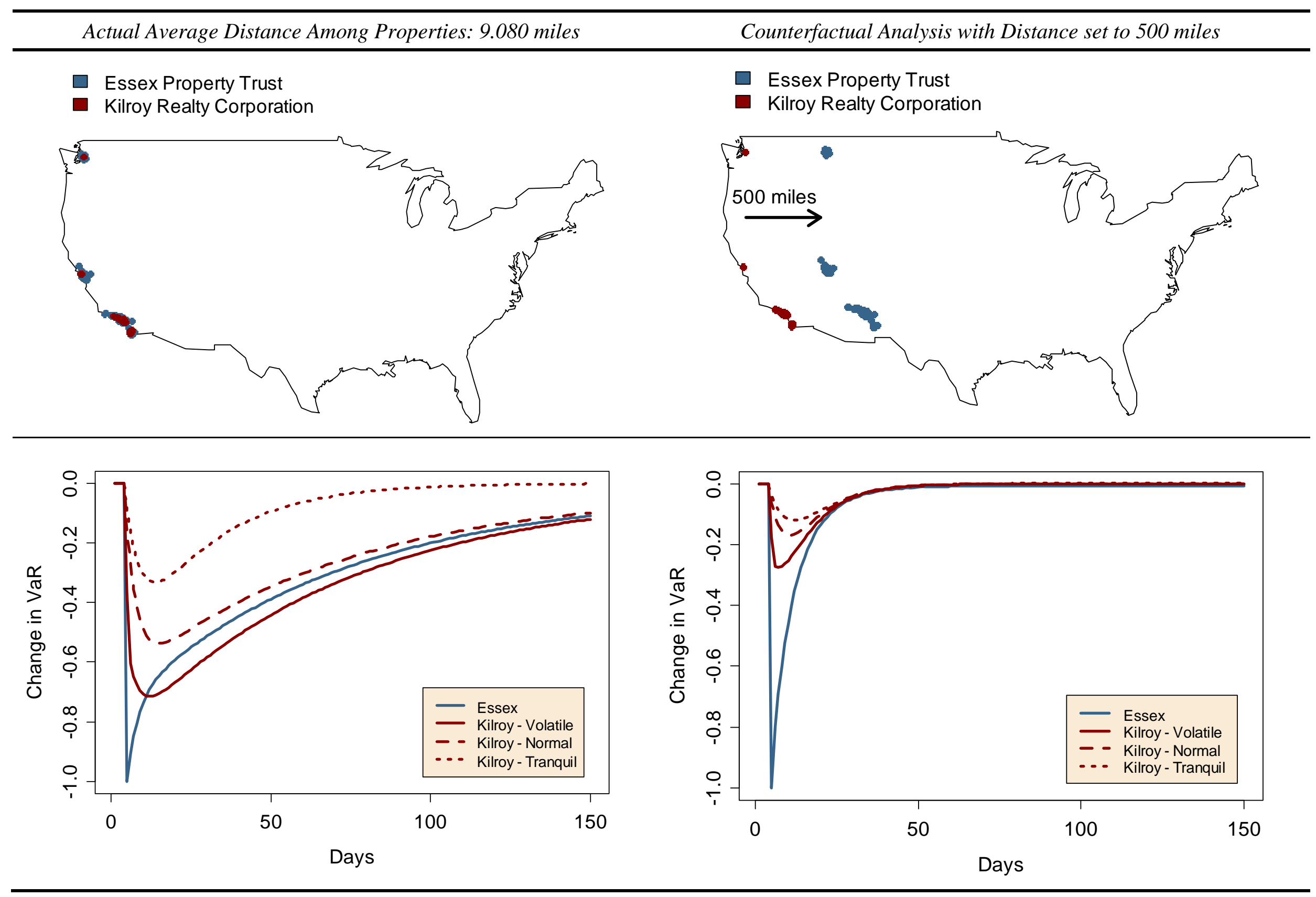


This figure presents the impulse response functions that demonstrate the dynamic behaviour of a system of two REITs in the presence of a one-time shock to one of the REITs, Essex Property Trust and Kilroy Realty Corp. (upper left graph), for each financial state. The two companies have their properties located in the same regions with an estimated distance of 9 miles. The upper right graph shows a simulation when shifting the properties of Essex Property Trust 500 miles away from their initial location. The lower left graph presents the impulse response functions for the current situation, whereas the lower right graph demonstrates the reaction to a shock in the counterfactual situation. 